\title{
Mineralogy and geochemistry of Fe-Ti oxide ores from the Don Dieguito massif- type anorthosite suite, Sierra Nevada de Santa Marta, Colombia
}

\author{
Mineralogía y geoquímica de las menas de óxidos de Fe-Ti en la anortosita de Don Dieguito, \\ Sierra Nevada de Santa Marta, Colombia
}

\author{
Sebastián Betancur-Figueroa ${ }^{1,2}$, Cristina Villanova-de-Benavent ${ }^{*, 2}$, Joaquín A. Proenza ${ }^{2}$, \\ Marion B. Weber ${ }^{1}$, Natalia Acevedo ${ }^{1}$, Antonio García-Casco ${ }^{3}$
}

${ }^{1}$ Departamento de Geociencias y Medio Ambiente, Facultad de Minas, Universidad Nacional de Colombia, Avenida 80 \# 65-223, 050034, Medellín, Colombia.

\footnotetext{
${ }^{2}$ Departament de Mineralogia, Petrologia i Geologia Aplicada, Facultat de Ciències de la Terra, Universitat de Barcelona, C/ Martí i Franquès s/n, 08028, Barcelona, Spain

${ }^{3}$ Departamento de Mineralogía y Petrología, Facultad de Ciencias, Universidad de Granada, Avda. Fuentenueva s/n, 18002 Granada, Spain.

* Corresponding author: (C. Villanova-de-Benavent)cvillanovadb@ub.edu
}

\begin{abstract}
How to cite this article:
Betancur-Figueroa, S., Villanova-de-Benavent, C., Proenza, J.A., Weber, M.B., Acevedo, N., García-Casco, A., 2020, Mineralogy and geochemistry of $\mathrm{Fe}-\mathrm{Ti}$ oxide ores from the Don Dieguito massif-type anorthosite suite, Sierra Nevada de Santa Marta, Colombia: Boletín de la Sociedad Geológica Mexicana, 72 (3), A200720. http://dx.doi.org/10.18268/ BSGM2020v72n3a200720
\end{abstract}

Manuscript received: February 24, 2020

Corrected manuscript received: September 10, 2020 Manuscript accepted: September 24, 2020

Peer Review under the responsability of Universidad Nacional Autónoma de México.

This is an open access article under the CC BY-NC-SA license(https://creativecommons.org/licenses/by-nc-sa/4.0/)

\begin{abstract}
$\mathrm{Fe}-\mathrm{Ti}$ oxide ores are commonly associated with Proterozoic massif-type anorthosite bodies emplaced during the Grenville orogeny ( 1.2-1.0 Ga). Some of these anorthositic bodies occur in the northernmost part of the Santa Marta Massif, Colombia. They locally contain crosscutting $\mathrm{Fe}-\mathrm{Ti}(-\mathrm{V})$ ore bodies between the El Hierro creek and the Don Dieguito river. We have distinguished two types of $\mathrm{Fe}-\mathrm{Ti}(-\mathrm{V})$ ores: i) oxide-apatite norite (fine grained ilmenite and magnetite disseminated in an assemblage of apatite, amphibole, chlorite, rutile and sericitized plagioclase) and ii) banded nelsonite (coarser grained ilmenite, magnetite and apatite distributed in bands, with minor baddeleyite, srilankite and högbomite). Ilmenite in the two ore types display distinct hematite exsolution features: a) needle-like in the oxide-apatite norite ore; and b) two generations of exsolutions in the banded ore. Magnetite shows similar $\mathrm{Ti}$ and $\mathrm{V}$ contents in both ore types (0.4 wt $\% \mathrm{TiO}_{2}$ and 0.5 wt $\% \mathrm{~V}_{2} \mathrm{O}_{3}$ on average in the oxide-apatite norite ore, $0.5 \mathrm{wt} \% \mathrm{TiO}_{2}$ and $0.4 \mathrm{wt} \% \mathrm{~V}_{2} \mathrm{O}_{3}$ in the banded ore), whereas ilmenite has higher hematite, pyrophanite and geikielite components in the banded ore. The ores might have formed from the combination of fractional crystallization and magma mixing, with exsolution occurring probably at $575-600^{\circ} \mathrm{C}$. This first detailed mineralogical and textural study of $\mathrm{Fe}-\mathrm{Ti}(-\mathrm{V})$ oxide ores in anorthosite massifs from Colombia suggests that the Santa Marta Massif is an interesting target for future research.
\end{abstract}

Keywords: Fe-Ti oxide ores, V, exsolution, titanoferous hermatite, ilmenite, magnetite, massif anorthosite, nelsonite.

\section{RESUMEN}

Las mineralizaciones de óxidos de $\mathrm{Fe}-\mathrm{Ti}$ se asocian comúnmente a complejos anortosíticos proterozoicos (massif-type) emplazados durante la orogenia Grenvilliana ( 1.2-1.0 Ga). Algunos de estos cuerpos anortosíticos se encuentran en la parte septentrional del Macizo de Santa Marta, en Colombia. Localmente, éstos contienen cuerpos de óxidos de Fe-Ti(-V) entre la quebrada $\mathrm{El}$ Hierro y el río Don Dieguito. Se han distinguido dos tipos de mineralizaciones de $\mathrm{Fe}-\mathrm{Ti}(-\mathrm{V})$ : i) norita con óxidos y apatito (ilmenita y magnetita de grano fino diseminadas en una asociación de apatito, anfibol, clorita, rutilo y plagioclasa sericitizada); y ii) nelsonita bandeada (ilmenita, magnetita y apatito de grano grueso, distribuidos en bandas, con cantidades menores de baddeleyita, srilankita y högbomita). Las ilmenitas en los dos tipos de mineralizaciones muestran diferentes exsoluciones de hematites: con forma de aguja en la mena diseminada; y dos generaciones de exsoluciones en la mena bandeada. La magnetita presenta contenidos en Ti y $V$ similares en ambas mineralizaciones (un promedio de 0.4 wo \% $\mathrm{TiO}_{2}$ y 0.5 wt $\% \mathrm{~V}_{2} \mathrm{O}_{3}$ en la diseminada, 0.5 $w t \% \mathrm{TiO}_{2}$ y 0.4 wt $\% \mathrm{~V}_{2} \mathrm{O}_{3}$ en la bandeada), mientras que la ilmenita tiene mayor componente hematites, pirofanita y geikielita en la mena bandeada. Las menas se podrían haber formado por la combinación de cristalización fraccionada y mezcla de magmas, y la exsolución tendría lugar probablemente a $575-600^{\circ} \mathrm{C}$. Esta primera caracterización mineral y textural de los óxidos de $\mathrm{Fe}$-Ti(-V) en macizos anortosíticos en Colombia indica que la Sierra de Santa Marta es un objetivo interesante para investigaciones futuras.

Palabras clave: óxidos de Fe-Ti, V, exsolución, Ti-hermatita, ilmenita, magnetita, anortositas massif-type, nelsonita. 


\section{Introduction}

Fe-Ti oxide-apatite rocks (nelsonites) are relatively scarce worldwide, and their occurrence is commonly associated with anorthosite massifs (e.g. Charlier et al., 2015; Chen et al., 2013; Duchesne, 1999; Dymek and Owens, 2001). In the broader Circum-Caribbean region they have been reported mainly in Mexico (e.g. Cisneros de León et al., 2017; Solari et al., 2003; Ortega-Gutiérrez, 1978) associated with Massif-type anorthosites that are part of Grenvillian granulite terrains, and that are considered important for the paleogeographic reconstructions of Rodinia (Ortega-Gutiérrez et al., 2018 and references therein).

$\mathrm{Fe}-\mathrm{Ti}$ oxide ores in northern Colombia were first described by Tschanz et al. (1969) in the Sierra Nevada de Santa Marta (SNSM), where they are associated with isotropic and gneissic anorthosites (Alfonso et al., 1990; Tschanz, 1970). These Fe-Ti oxide ores have been generally poorly described, and their petrogenetic significance remains to be studied (Alfonso et al., 1990; Cortes Castillo, 2013; Tschanz, 1970). On one hand, dense vegetation and weathering conditions represent an obstacle to find appropriate outcrops and, on the other hand, indigenous cultures who currently live and govern the region, grant researchers a restricted access in order to protect the natural resources of the area. The aim of the present contribution is to study the mineralogy and geochemistry of the Fe-Ti(-V) oxide mineralizations of SNSM.

\section{Geological setting}

The Sierra Nevada de Santa Marta (SNSM) mountain range is a complex massif isolated and completely independent from the Andean chain. It is located in northern Colombia and covers a range of altitudes from the sea level to close to $5,700 \mathrm{~m}$.

The SNSM is composed of a series of geological units surrounded by Mesozoic and Cenozoic sedimentary basins and intruded by plutons of different ages (Piraquive, 2017; Cardona et al., 2010a, 2010b; Tschanz et al., 1969; 1974). The current configuration of the SNSM is the result of the Late Meso-Cenozoic east-northeast migration of the Caribbean plate, and the movement of the northern Andean block associated with the subduction of the Pacific plate (Montes et al., 2010; Bayona et al., 2010; Cardona et al., 2010a; Pindell et al., 1998). It is limited by three large regional fault systems: the Santa Marta-Bucaramanga Fault System trending SE-NW, the Media Luna Fault trending SW-NE, and the Oca Fault trending WE (Tschanz et al., 1969). These three fault systems shape the range to the final triangle-like outline (Figure 1, Tschanz et al., 1969). The basement of the SNSM comprises a series of Precambrian rocks older than $\sim 1 \mathrm{Ga}$, subsequent complex Paleozoic metamorphic belts and several Mesozoic to Neogene intrusions (Tschanz et al., 1969).

The SNSM has been divided into four different provinces in terms of their age, petrology and structures (Figure 1; Tschanz et al., 1969; 1974; Piraquive, 2017). From northwest to southeast they are: 1) the Eocene Santa Marta Province, or Santa Marta Orogenic Belt, 2) the polymetamorphic Sevilla Arch Province or Sevilla Metamorphic Belt, 3) the Precambrian Granulite Province or Sierra Nevada Province, and 4) the Perijá Province, across the Cesar valley.

The Eocene Santa Marta Orogenic Belt consists in turn of two metamorphic units separated by the Eocene Santa Marta Batholith (Figure 1): 1) the Santa Marta Schists (also the Outer Santa Marta Metamorphic Belt), which lie to the west of the batholith and include greenschists, epidote-amphibolite facies rocks and metavolcanics; and 2) The Santa Marta Metamorphic Belt (also Inner Santa Marta Metamorphic Belt), which comprises the San Lorenzo and the Gaira Schists. These rocks are possible allochthonous fragments formed during accretionary events of the Mesozoic and Cenozoic (Bustamante et al., 2009; Tschanz et al., 1969).

The Sevilla Metamorphic Belt controls the current configuration of the SNSM. It is constrained by the Sevilla Lineament, a first order structure whose features limit the surface of a subduction 


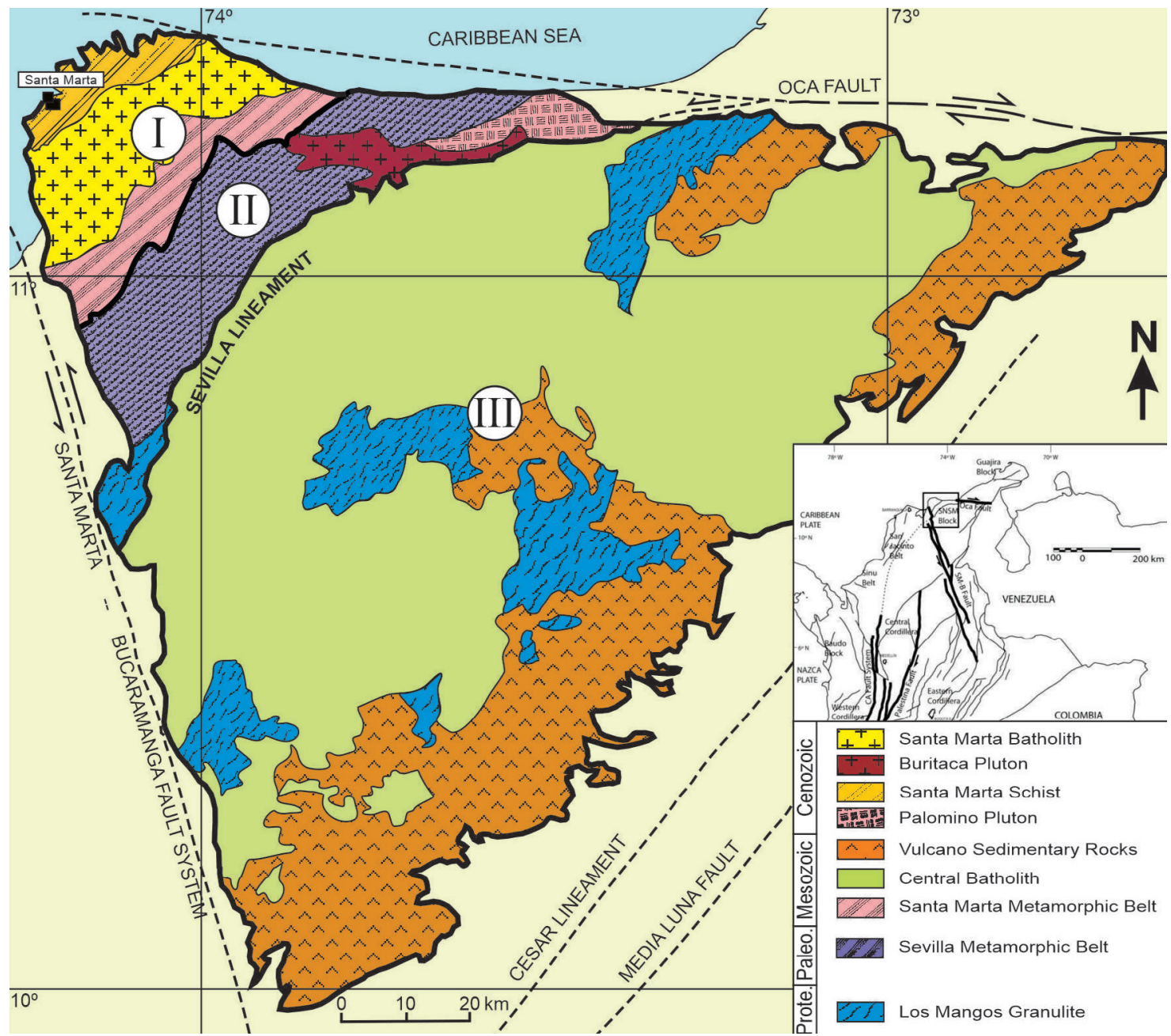

Figure 1 Geological map of the SNSM. I- Eocene Santa Marta Orogenic Belt. II- The Sevilla Metamorphic Belt. III- Precambrian granulite province (Modified after Tschanz et al., 1969).

zone during the Upper Permian and Triassic (Piraquive, 2017; Cardona et al., 2010a, 2010b; Tschanz et al., 1969). Along this structure, mafic and anorthositic gneisses, schists and allochthonous blocks of granulites crop out, the latter making part of a Neoproterozoic arc that existed during Rodinia break-up and was later metamorphosed in Permian-Triassic times, possibly during the Laurentia-Gondwana collision (Piraquive, 2017). Different magmatic events are found to intrude the Sevilla lineament causing the formation of several parallel structures, among these, the Eocene Buritaca pluton, in contact with the Precambrian anorthosites and other Permian, Cretaceous and Paleogene magmatic bodies (Tschanz et al., 1969).
Finally, the Precambrian Granulite Province (Bustamante et al., 2009; Tschanz et al., 1969) is the largest and oldest province in the massif. A Grenvillian oceanic crust makes up the basement of this province along with a series of gneisses, amphibolites, garnet-rich granulites and anorthosites (Tschanz et al., 1969). It is intruded by Jurassic plutons and it is mostly covered by volcanosedimentary rocks of Jurassic age. The granulites are affected by a set of transcurrent faults and show wide fragmentation by the intrusion of younger igneous bodies, such as the Jurassic Central Batholith and the Eocene Buritaca Pluton. This province can be associated to the Sunsas-Putumayo province (Ibáñez-Mejía et al., 2011), and represents one of the exposed Grenvillian inliers in Colombia (see review in Kroonenberg, 2018). 


\subsection{LOGAL GEOLOGY}

The study area is located in El Hierro creek, a medium-sized tributary of the Don Dieguito river, at the northern slope of the SNSM, near the Don Diego river (Figure 2). In this location, Tschanz (1969) reported the occurrence of minor ilmenite-apatite mineralization related to the Precambrian Don Dieguito Anorthosites. The main units that outcrop along the studied area are: 1) Los Mangos granulite, 2) Don Dieguito Anorthosite, 3) Santa Marta batholith and the Buritaca pluton, covered by alluvial terraces.

\subsubsection{LOS MANGOS GRANULITE}

This unit forms the metamorphic basement of the major part of the SNSM with an approximate extension of $1150 \mathrm{~km}^{2}$. The granulites are overlain by sedimentary and volcanic rocks and are intruded by different batholiths. The Los Mangos granulite comprises a series of parallel layers of alternating metamorphosed dark and light granulite facies gneisses, often migmatitic. They include 1) light-colored granitic granulites which include calcsilicate rocks and diopside marbles, 2) dark-colored, dense mafic and ultramafic granulites (e.g. peridotites), and 3) granulites of intermediate composition (Ordóñez-Carmona et al., 2002; Alfonso et al., 1990; Tschanz et al., 1969).

Light grey quartz-feldspathic gneisses with a massive appearance and granoblastic texture, medium to coarse grained, make up the first of the three groups mentioned above. They are mainly composed of plagioclase (oligoclase), quartz, biotite, with sericite and chlorite as alteration minerals. The second group consists of layers of dark grey hornblende-biotite gneisses up to $50 \mathrm{~cm}$ in width inside the quartz-feldspathic gneisses; and are medium to coarse-grained and with a granoblastic texture. The primary minerals are hornblende, biotite, quartz and plagioclase (oligoclase), with epidote, magnetite and sericite as accessory minerals (Tschanz et al., 1969). Finally, the intermediate granulites vary in composition from quartz diorite to trondjemite. Minerals of the granulite facies are scarce and secondary minerals are abundant, such as biotite and amphibole. Plagioclase is commonly oligoclase, present with green clinopyroxene, microcline and quartz (Tschanz et al., 1969). The unit is in contact with the Don Dieguito Anorthosite and the Buritaca pluton (Tschanz et al., 1969).

\subsubsection{DON DIEGUITO ANORTHOSITE}

The Don Dieguito Anorthosite was first recognized by Tschanz et al. (1969) in the El Hierro creek. Together with the other anorthosites of the SNSM, it is the third occurrence of anorthosites described in South America, after the Capivarito Anorthosite in Rio Grande do Sul, Brasil (Chemale et al., 2011) and the ones in Sierras Pampeanas, Argentina (Casquet et al., 2005), all of them yielding Precambrian ages. The Don Dieguito anorthosite is a beige, locally light pink to brownish rock, with isotropic to foliated structure and massive appearance. Within these rocks, the ilmenite-apatite-magnetite mineralization can be observed, both layered and podiform, which gives the rock a spotted aspect. According to Tschanz et al. (1969), at least $80 \%$ of the rock is composed mainly of coarse-grained twinned plagioclase that ranges from labradorite to oligoclase with a protoclastic texture and locally fractured; the remaining $20 \%$ is made up of augen-like mafic minerals such as hornblende and biotite displaying granoblastic texture (Alfonso et al., 1990; Tschanz et al., 1969). The gneissic anorthosite and accessory magnetite are considered to be plagioclase gneisses that form lenses or concordant layers within the Precambrian granulites (Alfonso et al., 1990). The primary mafic minerals are completely replaced by secondary pale green actinolitic amphibole, low iron chlorite and low iron epidote. Biotite and muscovite are also common secondary minerals. Traces of quartz and calcite are locally present (Alfonso $e t$ al., 1990; Tschanz et al., 1969). The Don Dieguito Anorthosite is associated to a coarse-grained equigranular rock, composed mainly of oligoclase.

Tschanz et al. (1969) described two types of magnetite or apatite-ilmenite mineralizations in the Don Dieguito river area: 1) mafic dykes, very 


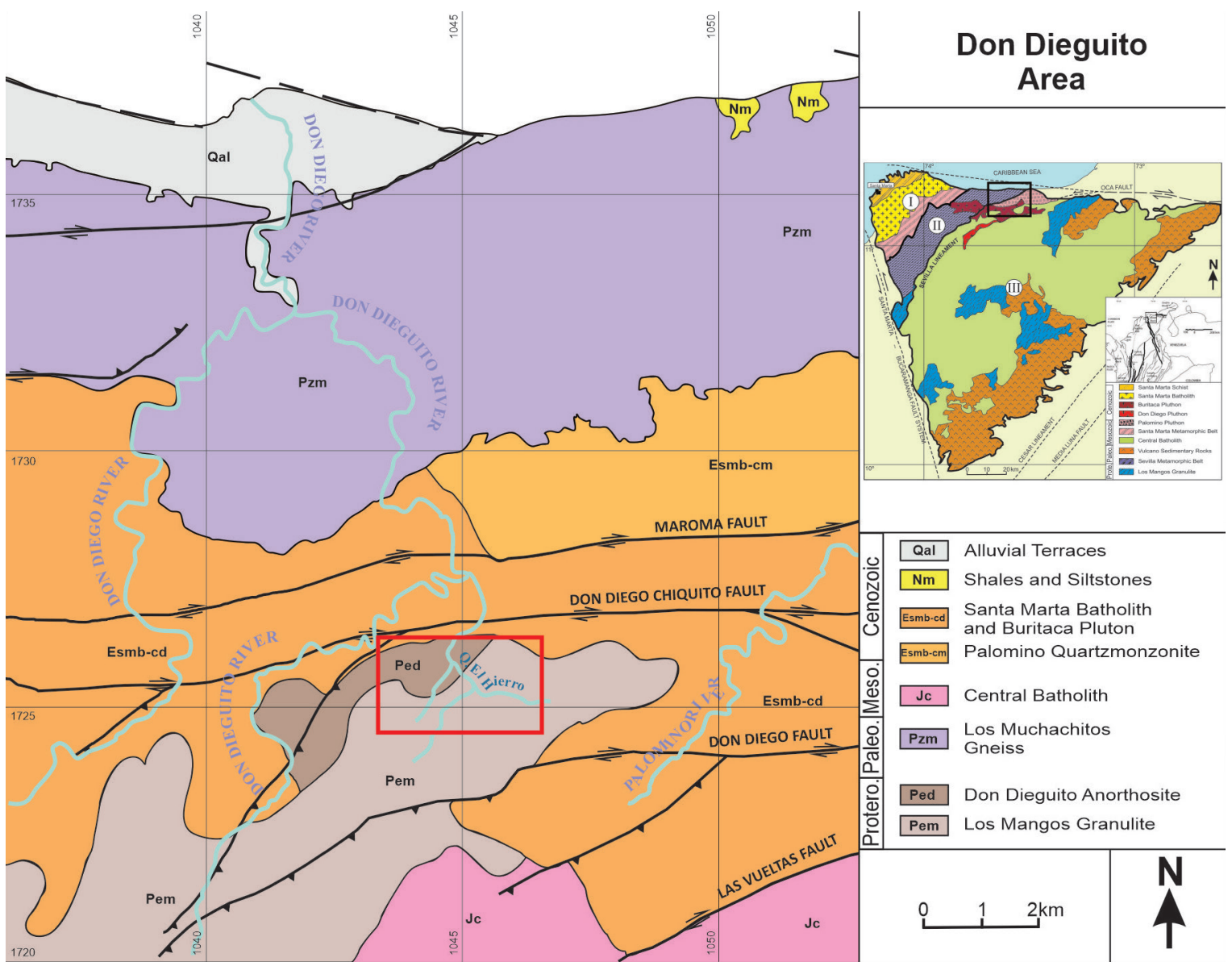

Figure 2 Geological map of the Don Dieguito river area (red area). Note the El Hierro creek in the central part of the map flowing towards the Don Dieguito river, which cuts the Los Mangos Granulite (Pem) and the Don Dieguito Anorthosite (Ped). Modified after the Colombian Geological Survey (SGC, 2019).

rich in apatite and ilmenite, and ilmenite veins with accessory magnetite; 2) a bimineralic banded apatite-ilmenite rock closely associated with the Don Diego Anorthosite. Although it is difficult to accurately locate the ilmenite-apatite mineralized zones, great amounts of boulders and cobbles of these rocks are found along the El Hierro creek.

Gabbroid rocks (mineralized norites), amphibole rich rocks, diorites and plagioclase (oligoclase) dykes locally crosscut the anorthosite. The genetic relationship between these rocks and the Don Dieguito Anorthosite is still uncertain (Alfonso et al., 1990; Tschanz et al., 1969). The contact between the Don Dieguito Anorthosite and the Los Mangos Granulite has not been well established yet (Tschanz et al., 1969).

\subsubsection{SANTA MARTA BATHOLITH AND THE BURITACA PLUTON}

This unit comprises two Eocene igneous bodies (Colmenares et al., 2007; Tschanz et al., 1969; 1974). The Buritaca pluton intrudes the Los Mangos Granulites and the Don Dieguito Anorthosite. The composition is biotite and hornblende tonalite, but also diorite, granodiorite and granite.

\section{Materials and methods}

\subsection{SAMPLING}

The studied samples were taken along the El Hierro creek. Many black, massive and heavy boul- 
ders and cobbles were observed on the riverbed indicating the existence of an ore body upstream the creek. The only accessible outcrop is located approximately $1.2 \mathrm{~km}$ from the El Hierro river mouth to the Don Dieguito river. Two boulder samples were selected for this study, representative of the two mineralization styles observed: NEL002-I for the banded nelsonite and NEL-002-J for the oxide-apatite norite.

\subsection{BULK ROGK GEOGHEMISTRY}

Major element compositions were determined at the Activation Laboratories Ltd. (Actlabs, Ontario, Canada) by X-ray fluorescence (XRF). Precision was better than \pm 1.5 wt. $\%$ for a concentration of $\geq 10$ wt. $\%$ and $\pm 2 \mathrm{wt} \%$ for a concentration $\leq 10$ wt. $\%$. The concentration of trace elements, including rare earth elements (REE, La-Lu+Y) was determined by acid dissolution using ICP-MS (WRA4B2).

\subsection{POWDER X-RAY DIFFRACTION (PXRD)}

The samples were carefully ground using an agate mortar and pestle and were prepared manually pressing the powders in cylindrical standard containers of $16 \mathrm{~mm}$ diameter and $2.5 \mathrm{~mm}$ height, in order to obtain the flattest possible surface. The diffractograms were obtained using a PANalytical X'Pert PRO MPD Alphal powder diffractometer (Centres Científics i Tecnològics of the University of Barcelona - GCiT-UB, Barcelona, Spain), in Bragg-Brentano $\theta / 20$ geometry of $240 \mathrm{~mm}$ of radius, nickel filtered $\mathrm{Cu} \mathrm{Ka}$ radiation $(\lambda=$ $1.5418 \AA), 45 \mathrm{kV}-$ and $40 \mathrm{~mA}$. During analysis, samples were spun at 2 revolutions per second. Axial divergence Soller slits of 0.04 radians were used. Samples were scanned from $4^{\circ}$ to $80^{\circ}(2 \theta)$ with a step size of $0.017^{\circ}$ and measuring time of 50 s per step, using a X'Celerator detector (active length $=2.122^{\circ}$ ), and a primary Ge monochromator. The detailed structural characterization and the semiquantitative mineral determination were performed by full profile analyses of the powder diffractograms using the software TOPAS version 4.0 (Rietveld method). This method was comple- mented with the mineral proportions obtained by examining the polished sections and polished thin sections.

\subsection{SGANNING ELEGTRON MIGROSGOPE (SEM)}

Samples NEL-002-I and NEL-002-J were prepared as polished sections and polished thin sections for the study under the optical microscope using both reflected and transmitted light. They were carbon coated and examined under the ESEM Quanta 200 FEI scanning electron microscope, couples to an Energy Dispersive Spectrometer (SEM-EDS) Inca 250 (CCiT-UB, Barcelona, Spain). The microscope was set at $15 \mathrm{kV}$ and $5 \mathrm{nA}$ in backscattered electron (BSE) mode.

\subsection{ELEGTRON MIGROPROBE ANALYSIS (EMPA)}

Chemical analyses of the mineral phases of samples NEL-002-I and NEL-002-J were performed using a JEOL JXA-8230 electron microprobe (EMP) at the CCiT-UB, equipped with four wavelength dispersive spectrometers (WDS) and one energy dispersive spectrometer (EDS) operated at $20 \mathrm{kV}$ accelerating voltage, $15 \mathrm{nA}$ beam current and with a beam diameter of $5 \mu \mathrm{m}$, and $1 \mu \mathrm{m}$ for minute mineral grains. The analytical standards used were: hematite $(\mathrm{Fe})$, rutile $(\mathrm{Ti})$, periclase $(\mathrm{Mg})$, rhodonite $(\mathrm{Mn})$, corundum $(\mathrm{Al})$, $\mathrm{Cr}_{2} \mathrm{O}_{3}(\mathrm{Cr})$, metallic vanadium $(\mathrm{V})$, diopside $(\mathrm{Si})$, sphalerite $(\mathrm{Zn}), \mathrm{NiO}(\mathrm{Ni})$, wollastonite $(\mathrm{Ca})$ and metallic $\mathrm{Nb}(\mathrm{Nb})$. The correction procedure PAP (Pouchou and Pichoir, 1991) was used to convert specimen intensity ratios into concentrations. The Ti $\mathrm{K} \beta$ overlap on the $\mathrm{V}$ Ka peak was corrected by the microprobe software. The structural formulae calculations of magnetite were performed on the basis of 4 oxygens, and of ilmenite and hematite, with 3 oxygens; and using the criteria of Carmichael (1966) for the $\mathrm{Fe}^{3+}$ estimation. The ilmenite (Ilm), hematite (Hem), geikielite (Gk) and pyrophanite $(\mathrm{Pph})$ components were calculated as follows: $\mathrm{Ilm}=\left(\mathrm{Fe}^{2+} /\left(\mathrm{Fe}^{2+}+\mathrm{Fe}^{3+}+\mathrm{Mg}+\mathrm{Mn}\right)\right) \cdot 100$, $\mathrm{Hem}=\left(\mathrm{Fe}^{3+} /\left(\mathrm{Fe}^{2+}+\mathrm{Fe}^{3+}+\mathrm{Mg}+\mathrm{Mn}\right)\right) \cdot 100$, $\mathrm{Gk}=\left(\mathrm{Mg} /\left(\mathrm{Fe}^{2+}+\mathrm{Fe}^{3+}+\mathrm{Mg}+\mathrm{Mn}\right)\right) \cdot 100, \mathrm{Pph}=(\mathrm{Mn} /$ $\left.\left(\mathrm{Fe}^{2+}+\mathrm{Fe}^{3+}+\mathrm{Mg}+\mathrm{Mn}\right)\right) \cdot 100$; where $\mathrm{Fe}^{2+}, \mathrm{Fe}^{3+}, \mathrm{Mg}$ 
and $\mathrm{Mn}$ are in cations per formula unit. The calculation of the ulvöspinel (Usp) component in magnetite was obtained following Stormer (1983). The composition of $\mathrm{Fe}-\mathrm{Ti}(-\mathrm{V})$ oxides was plotted in triangular diagrams using the CSpace software (Torres-Roldán et al., 2000). Mineral and end member abbreviations are after Whitney and Evans (2010).

\section{Results}

In general terms, two distinct mineralization styles were identified, each with characteristic mineralogy and textures. On one hand, the oxide-apatite norite is characterized by having a dark greenish color, and contains ilmenite, apatite, and minor silicates and other oxides (represented by sample NEL-002J). On the other hand, the banded nelsonite presents a banded fabric, the bands consisting of alternating massive black ilmenite grains, and apatite grains embedded in ilmenite (represented by sample NEL-002I).

\subsection{MINERALOGY AND TEXTURES}

From PXRD, the oxide-apatite norite mineralization consists mainly of amphibole (38\%), apatite $(26 \%)$, chlorite $(12 \%)$, ilmenite $(9 \%)$ and magnetite $(4 \%)$ (Figure 3a). In contrast, the banded nelsonite is characterized by the presence of predominantly ilmenite and hematite, magnetite and apatite, and minor chlorite was detected in the apatite separate (Figure 3b and 3c). Moreover, for the banded style, separated analyses where done to obtain the mineral expression of both the ore (Figure 3b) and the rest of the minerals (Figure 3c), yielding a simple composition of ilmenite and apatite.

\subsubsection{OXIDE-APATITE NORITE ORE}

In general terms, the oxide-apatite norite displays an isotropic fabric, it is holocrystalline and finegrained (most of the grains are smaller than 1 $\mathrm{mm})$. The presence of amphibole and chlorite gives it a greenish color. In descending order of abundance, amphibole retrograded to chlorite is present in the sample in contact with apatite, ilmenite, sericitized plagioclase and pyrite (Figure 4). Granoblastic microstructures can be recognized between ilmenite and apatite grains displaying straight edges and triple points, therefore suggesting evidences of textural equilibrium (Figure $4 \mathrm{a}$ and $4 \mathrm{~b}$ ). Minor, scattered pyrite relicts are present as inclusions within some apatite grains, and are less than $20 \mu \mathrm{m}$ in size (Figure 4a, upper right). Altered, subhedral amphibole are found across the sample with light green tones and sizes ranging from a few hundreds of micrometers to some millimeters (Figure 4c). Stubby grains of apatite smaller than $300 \mu \mathrm{m}$ appear across the sample, both as inclusions within the amphibole, and as individual grains (Figure 4d). In contrast, minor plagioclase crystals range from sub- to euhedral and display polysynthetic twinning and alteration to sericite (Figure 4d).

Large, anhedral grains of magnetite make up no more than $5 \mathrm{vol} \%$ of the sample and tend to have serrated edges close to the ilmenite grains (Figure 4e), and no exsolved phases are observed within the magnetite grains. Ilmenite displays different titaniferous hematite exsolutions, including both a high lamellae density (Figure 4f) and the absence or fewer lamellae (Figure 4g). The very narrow needle-like titaniferous hematite lamellae are characteristic of this mineralization style, and are systematically aligned following the $\{0001\}$ ilmenite planes. These lamellae display a mildly constant width ranging between 5 and $10 \mu \mathrm{m}$; however, thicker lamellae, as the ones observed in Figure $4 \mathrm{~h}$ (center right of the image), might form when narrow lamellae weld or are in contact with each other. In some cases, external grain exsolutions can be observed (Figure 4g; NW ilmenite border).

\subsubsection{BANDED NELSONITE ORE}

The banded nelsonite presents an equidimensional grain size $(<1 \mathrm{~mm})$ and an ilmenite/apatite ratio close to $50 / 50$ (Figure 5a). The rock has a 
a) Oxide-apatite norite

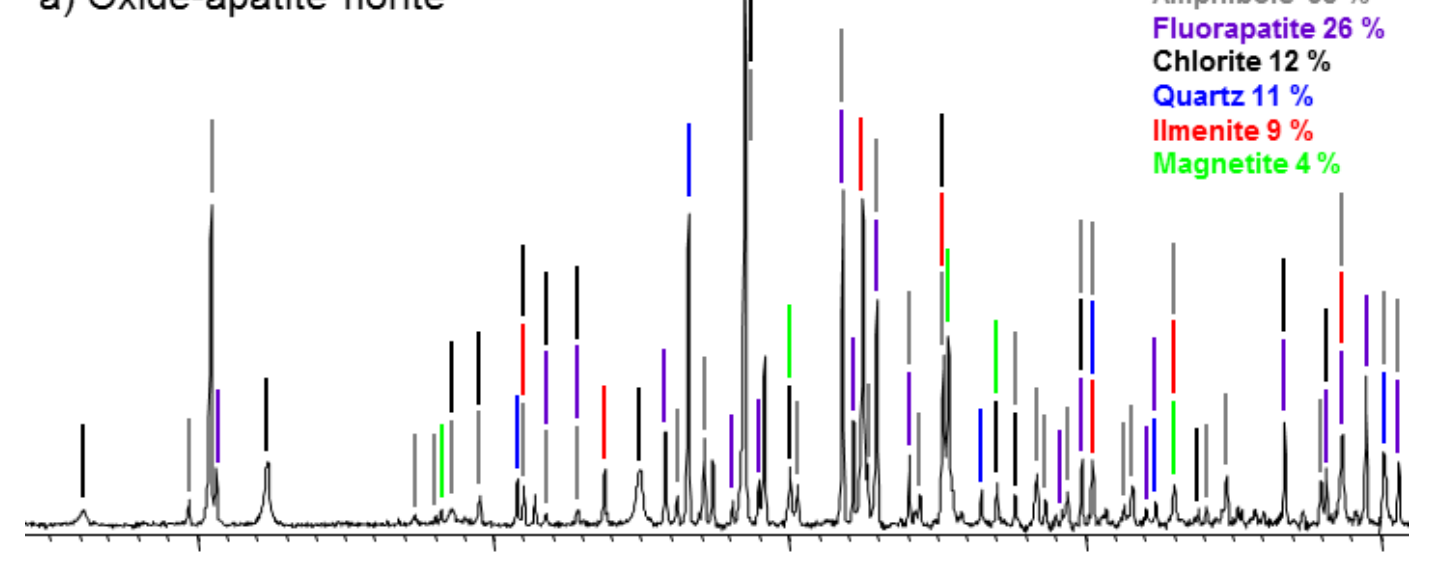

b) Banded nelsonite (oxide separate)
Ilmenite $63 \%$

Hematite $37 \%$ c) Banded nelsonite (apatite separate)

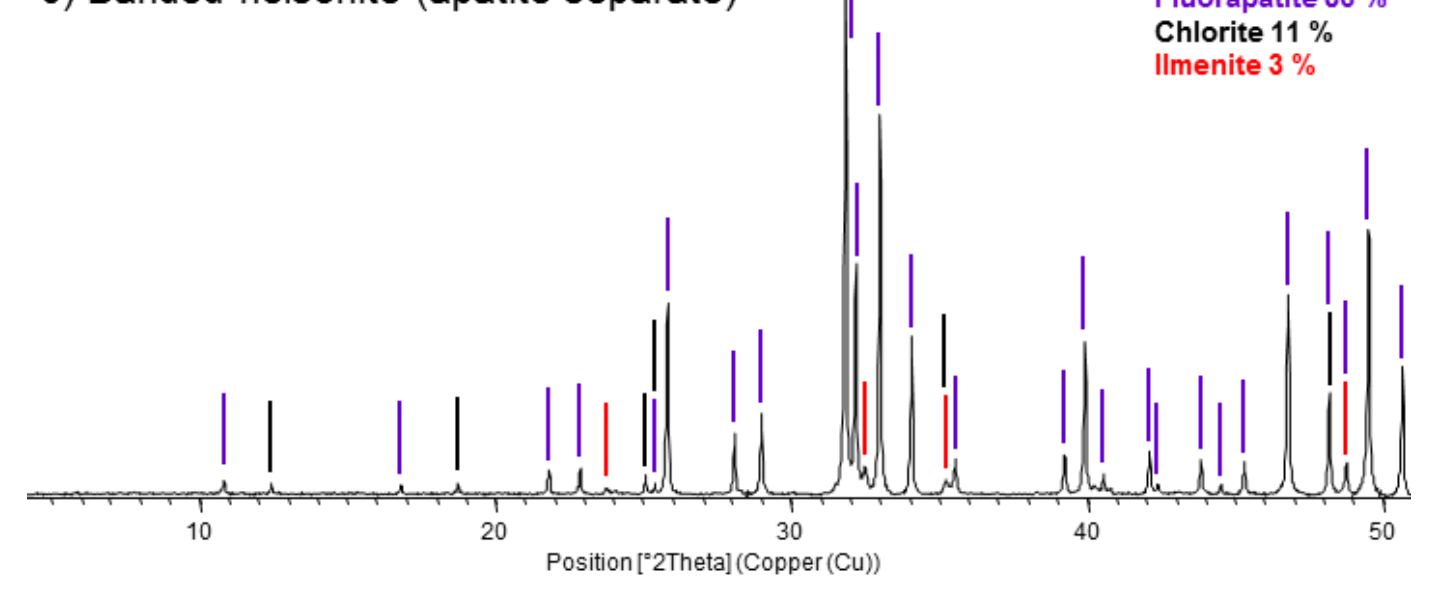

Figure 3 X-ray diffractograms (blue) with semiquantitative mineralogy of samples NEL-002-J (a: whole rock) and NEL-002- (b: Fe-Ti oxide; c: apatite grains), including the percentage of each mineral identified. Note the presence of amphibole and the abundance of chlorite in the oxide-apatite norite ore. The background is displayed in green lines. 

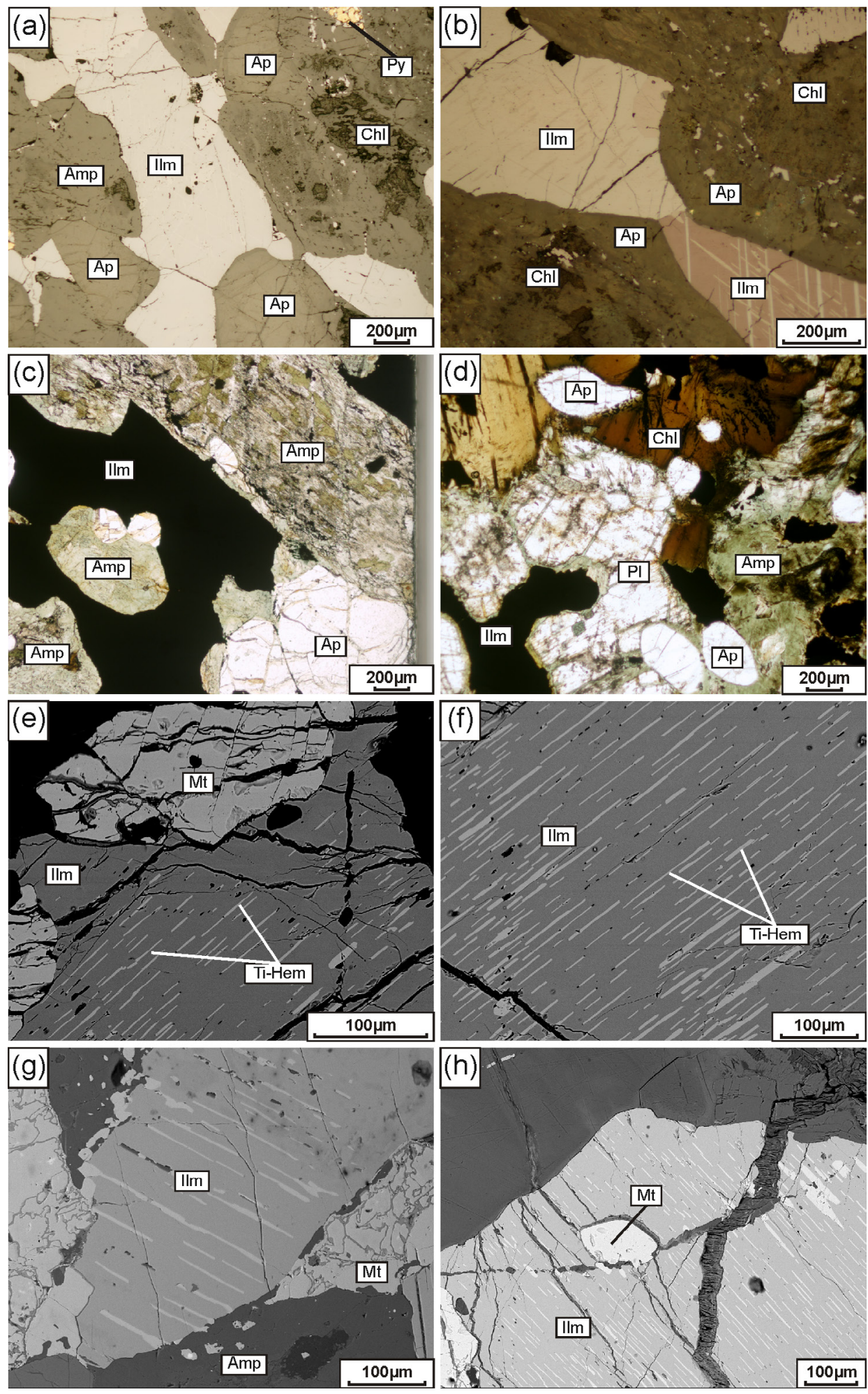

Figure 4 Optical (a, reflected, plane polarized light; b, reflected, crossed polars; c, d, transmitted, plane polarized light) and backscattered electron (BSE) micrographs (e,f,g,h,i: CCiT-UB) showing the most representative textures of the Fe-Ti(-V) oxide-apatite norite ore from the Sierra Nevada de Santa Marta (SNSM), Colombia: (a) apatite grains with pyrite inclusions, in textural equilibrium with ilmenite in a granoblastic microstructure; (b) ilmenite grains surrounded by apatite and chlorite; (c) altered greenish euhedral amphibole with stubby grains of apatite; (d) sericitized plagioclase in contact with apatite, chlorite and amphibole; (e,f) anhedral grains of magnetite with serrated edges in contact with ilmenite grains with needle-like titaniferous hematite lamellae; (g) large ilmenite grains with hematite lamellae, surrounded by amphibole and magnetite (note the spinel rim in the SE ilmenite border with magnetite, and the external grain exsolutions in the NW ilmenite border with the amphibole); ( $h$ ) thicker lamellae produced by agglomeration of contiguous lamellae (center, right. Mineral abbreviations are after Whitney and Evans (2010). 

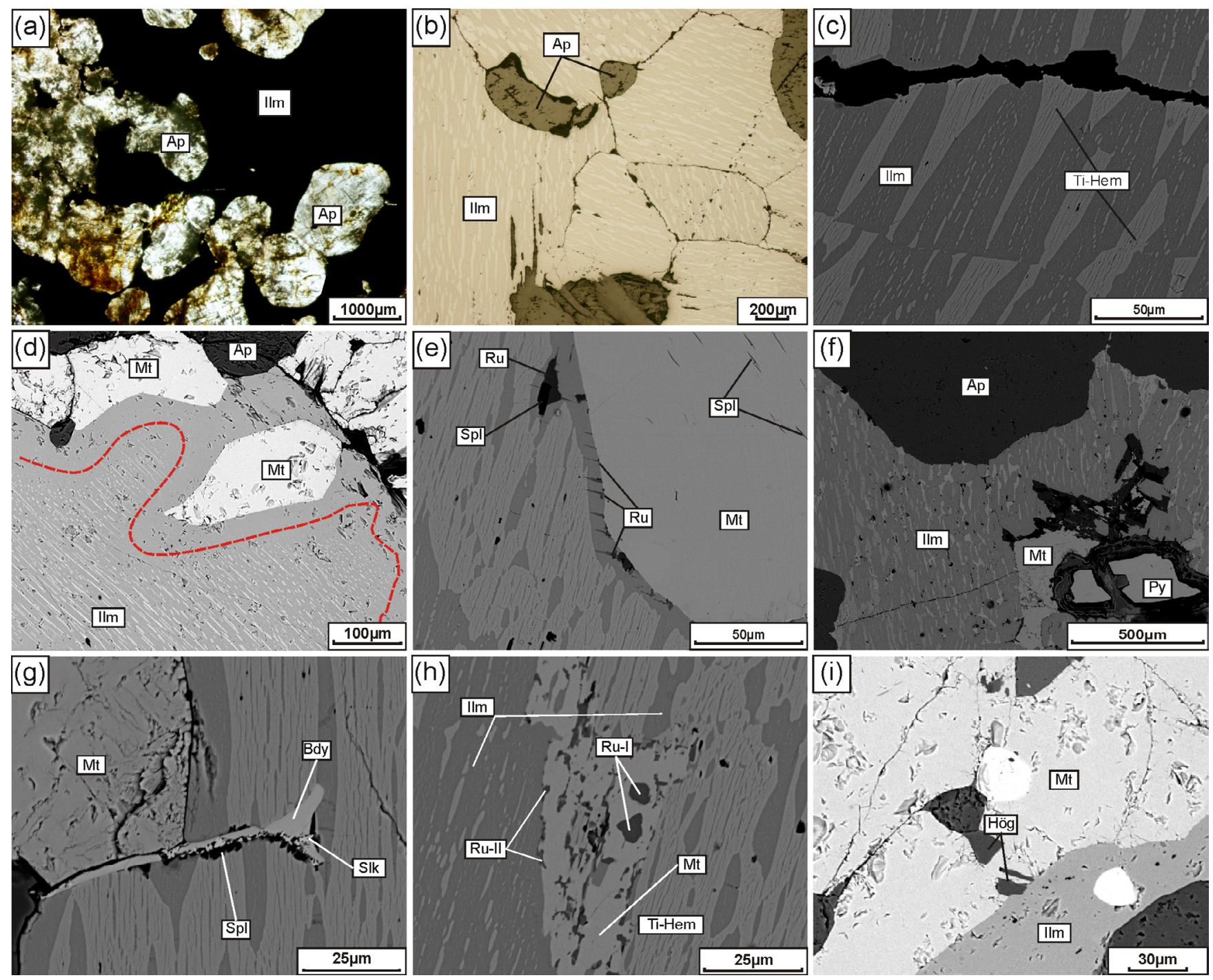

Figure 5 Optical (a, transmitted, plane-parallel light; $b$, reflected, plane parallel light) and backscattered electron (BSE) micrographs (c,d,e,f,g,h,i: CCiT-UB) showing the most representative textures of the banded nelsonite from the Sierra Nevada de Santa Marta (SNSM), Colombia: (a) nelsonite exhibiting rounded grains of apatite with a greenish alteration within ilmenite; (b) equilibrium textures between apatite and exsolved ilmenite grains; (c) patchy and minute exsolution lamellae exsolving from the ilmenite grains; (d) halo of a lamellae-free zone in the border of the ilmenite grain (outlined by the dashed line); (e) magnetite grains containing spindle-like grains of spinel and rutile needles in the contact with ilmenite; (f) presence of pyrite altered to iron oxides; (g) presence of srilankite (SIk) along with a baddeleyite (Bdy) lath in the border between magnetite and ilmenite; (h) symplectitic texture between magnetite and rutile; (i) possible presence of Zn-bearing spinel (dark grey) and spinel/hercynite (black) in ilmenite. Mineral abbreviations are after Whitney and Evans (2010).

banded fabric with an alternating arrangement of apatite-rich bands and ilmenite-rich bands. Large, well-developed grains ranging between 0.5 and 1 $\mathrm{mm}$ in diameter of both ilmenite and apatite are recognizable on polished surfaces of the hand specimen. The banded nelsonite ore presents a granoblastic microstructure, more evident than in the oxide-apatite norite, with triple points and sharp contacts between grains (Figure 5b). Ilmenite is characterized by the ubiquitous presence of two generations of titaniferous hematite exsolutions, parallel to $\{0001\}$ ilmenite crystallization planes (Figure 5c). The first generation (hemo-ilmenite), coarser and patchy, or irregular-shaped, contains in turn later ilmenite lamellae. The second generation (ilmeno-hematite) consists of abundant minute lamellae scattered around the first generation exsolutions (Figure 5c). These exsolution features were first described by Hargraves (1959) and Carmichael (1961), and have also been reported by 
McEnroe et al. (2002, 2007), Hebert et al. (2005), and Charlier et al. (2010), among others, in Canadian and Norwegian Fe-Ti oxide ores associated with anorthosite intrusives.

Some magnetite grains display nanometric spindle-like exsolutions of possibly spinel (too small to be analyzed) following the $\{100\}$ directions of magnetite (Figure 5d, upper right). Lamellae-free halos may develop along the border of ilmenite when it is in contact with magnetite, as shown with the dashed line in Figure 5d. The decrease of hematite component towards the ilmenite rim was pointed out by Charlier et al. (2015) and references therein (Figure 5e). Hematite-rich areas within ilmenite grains may show ilmenite exsolutions, in some sort of inverse exsolution relationship. In this case, an exsolution-free border is locally found near the boundary with magnetite, where parallel rutile needles may grow on the magnetite-ilmenite boundary and inside the ilmenite grain (Figure 5e). Even though the banded nelsonite comprises primarily ilmenite and apatite, some isolated grains of pyrite are recognizable, generally altered to iron oxyhydroxides to the edges (Figure 5f).

In addition, a Y-shaped baddeleyite lath has been observed between two grains of magnetite and ilmenite. Around and inside this lath, small grains of possibly srilankite $\left(\mathrm{Ti}_{2} \mathrm{ZrO}_{6}\right)$ are found (identified from SEM-EDS), along with minute spinel grains surrounding baddeleyite (Figure $5 \mathrm{~g}$ ).

Furthermore, a symplectitic texture is observed between rutile and magnetite grains (Figure 5h), with two different grain size groups and their location in relation with magnetite, possibly indicating different rutile formation stages: rutile I is embedded in the magnetite while rutile II is present along its margins. Finally, it must be noted that small amounts of a Zn-bearing minerals are present as small grains in contact with magnetite and ilmenite, possibly belonging to the högbomite group (Figure 5i), with 1.7-11.8 wt. \% $\mathrm{ZnO}$ and 5.06-6.75 wt. \% $\mathrm{TiO}_{2}$ (7 analyses). Högbomite group minerals have been reported in other Fe-Ti oxide deposits (e.g., Devaraju et al., 1981; Mohanty et al., 2000).

\subsection{BULK-ROGK GEOCHEMISTRY}

The two mineralization styles identified differ from each other mainly in the $\mathrm{TiO}_{2}$ content, which as expected, is higher in the banded nelsonite ore because of higher Fe-Ti oxide content (Table 1). The oxide-apatite norite ore contains 11 wt $\%$ $\mathrm{TiO}_{2}$ and $33 \mathrm{wt} \%$ total $\mathrm{Fe}\left(\mathrm{as} \mathrm{Fe}_{2} \mathrm{O}_{3}\right)$, whereas the banded nelsonite yields $31 \mathrm{wt} \% \mathrm{TiO}_{2}$ and $52 \mathrm{wt}$ $\% \mathrm{Fe}_{2} \mathrm{O}_{3}$, because of the differences in ilmenite, magnetite and hematite contents. Si content is much higher in the oxide-apatite norite ore (28 wt $\% \mathrm{SiO}_{2}$ ) than in the banded nelsonite $(0.6 \mathrm{wt}$ $\left.\% \mathrm{SiO}_{2}\right)$, because of the presence of silicates. For the same reason, the values of $\mathrm{CaO}$ and $\mathrm{MgO}$ are higher in the oxide-apatite norite ore in comparison to the banded nelsonite, reaching 12 and 7 wt $\%$ respectively. Finally, both the oxide-apatite norite ore and the banded nelsonite contain similar $\mathrm{P}_{2} \mathrm{O}_{3}$ (6 wt $\%$ and $7 \mathrm{wt} \%$, respectively). It is noteworthy that significant values of $\mathrm{V}$ and $\mathrm{Cr}$ are present in the banded mineralization style: 1857 ppm V and 280 ppm Cr.

Both the oxide-apatite norite and the banded nelsonite REE patterns depict a negative slope (Figure 6, Table 1). Additionally, both show a negative $\mathrm{Eu}$ anomaly. A comparison between the REE data in the studied nelsonites and other Fe-Ti(-V) oxide mineralizations around the world is displayed in Figure 6. Similarities in the spider diagrams of nelsonites found in Chiapas (Cisneros de León et al., 2017), Hestnes (Duchesne and Liégeois, 2015) and Kunene (Villanova-de-Benavent et al., 2017) indicate that the origin of the SNSM nelsonites could be similar. The Nelsonites in the Hestnes deposit are cumulates in an immiscible Fe-rich, Si-poor melt in oxidizing conditions (Duchesne and Liégeois, 2015).

\subsection{MINERAL GHEMISTRY}

\subsubsection{ILMENITE}

The chemical composition of ilmenite in the two mineralization types identified is very similar in terms of $\mathrm{Ti}$ and Fe (Figure 7, Table 2). In gen- 
eral, ilmenite from the SNSM has a $\mathrm{TiO}_{2}$ content ranging from 41.6 to $50.4 \mathrm{wt} \%(0.78-0.95 \mathrm{apfu}$ $\mathrm{Ti}, 37$ analyses) in the banded nelsonite, and from 49.2 to 50.1 wt \% (0.93-0.94 apfu Ti, 3 analyses) in the oxide-apatite norite. No relation between the amount of $\mathrm{Ti}$ and the location of the measured point has been observed when measuring ilmenite points close or away from the lamellae. Note that, in the element maps of Figure 8, there is no significant compositional variation between the portion of ilmenite in contact with the lamellae and the parts away from them (Figure $8 \mathrm{a}$ ). V content is low, ranging from 0.3 to $0.6 \mathrm{wt} \% \mathrm{~V}_{2} \mathrm{O}_{3}$ in the banded nelsonite, and of $0.4 \mathrm{wt} \% \mathrm{~V}_{2} \mathrm{O}_{3}$ in the oxide-apatite norite .

However, the hematite component varies from 4.5 to $21.3 \mathrm{~mol} \%$ (average of $10.4 \mathrm{~mol} \%$ ) in the banded nelsonite, and from 5.8 to 6.5 (average of $6.1 \mathrm{~mol} \%$ ) in the oxide-apatite norite .

In addition, ilmenite from the banded mineralization style contains between 0.2 and $6.6 \mathrm{wt} \%$ $\mathrm{MnO}$ which gives the mineral an important pyrophanite component (up to $14.9 \mathrm{~mol} \% \mathrm{Pph}, 5.2$ mol $\%$ Pph on average), and up to $5.1 \mathrm{wt} \% \mathrm{MgO}$ which translates into a remarkable geikielite component (up to $18.2 \mathrm{~mol} \% \mathrm{Gk}, 4.7 \mathrm{~mol} \% \mathrm{Gk}$ on average). In contrast, ilmenite from the oxide-ap- atite norite shows much lower pyrophanite and geikielite components $(3.2$ and $0.2 \mathrm{~mol} \%$, on average, respectively), since very low values of $\mathrm{MnO}$ (1.5 wt \% on average) and $\mathrm{MgO}$ (below 0.1 wt \% on average) were obtained (Figure 9).

Finally, measured points within the titaniferous hematite lamellae exsolved from ilmenite give highly variable $\mathrm{Ti}$ (Table 3, Figure 7). $\mathrm{TiO}_{2}$ in the banded nelsonite varies from 2 to 18.1 wt $\%$, but possible contamination from the ilmenite host cannot be discarded; and $\mathrm{V}$ ranges from 0.17 to 0.88 wt $\% \mathrm{~V}_{2} \mathrm{O}_{3}$.

Valid analyses of the patchy exsolutions in the banded nelsonite, and of the lamellae oxide-apatite norite mineralization style could not be obtained.

\subsubsection{MAGNETITE}

Magnetite grains in both mineralization styles do not differ significantly from each other in terms of chemical composition (Figure 7, Table 4). In the oxide-apatite norite, $\mathrm{Ti}$ content is too low to account for a titaniferous magnetite, with an average of 0.4 wt $\% \mathrm{TiO}_{2}(0.01$ apfu $\mathrm{Ti})$. In contrast, in the banded nelsonite it has an average of 0.5 wt $\% \mathrm{TiO}_{2}(0.01$ apfu $\mathrm{Ti})$, but it can reach up to

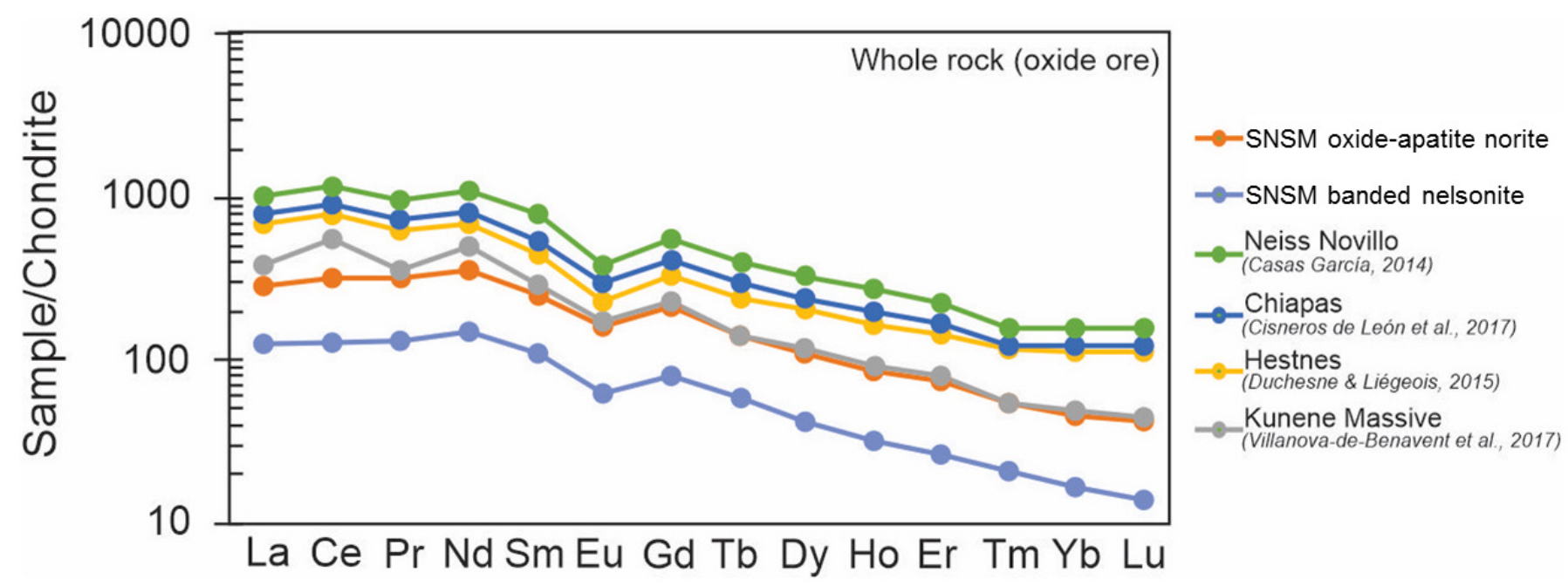

Figure 6 Spider diagram depicting the chondrite-normalized REE composition of the oxide-apatite norite and banded nelsonite oxide ores studied in the Sierra Nevada de Santa Marta, compared to values of other Fe-Ti(-V) oxide ores worldwide. Chondrite values are after McDonough and Sun (1994). 


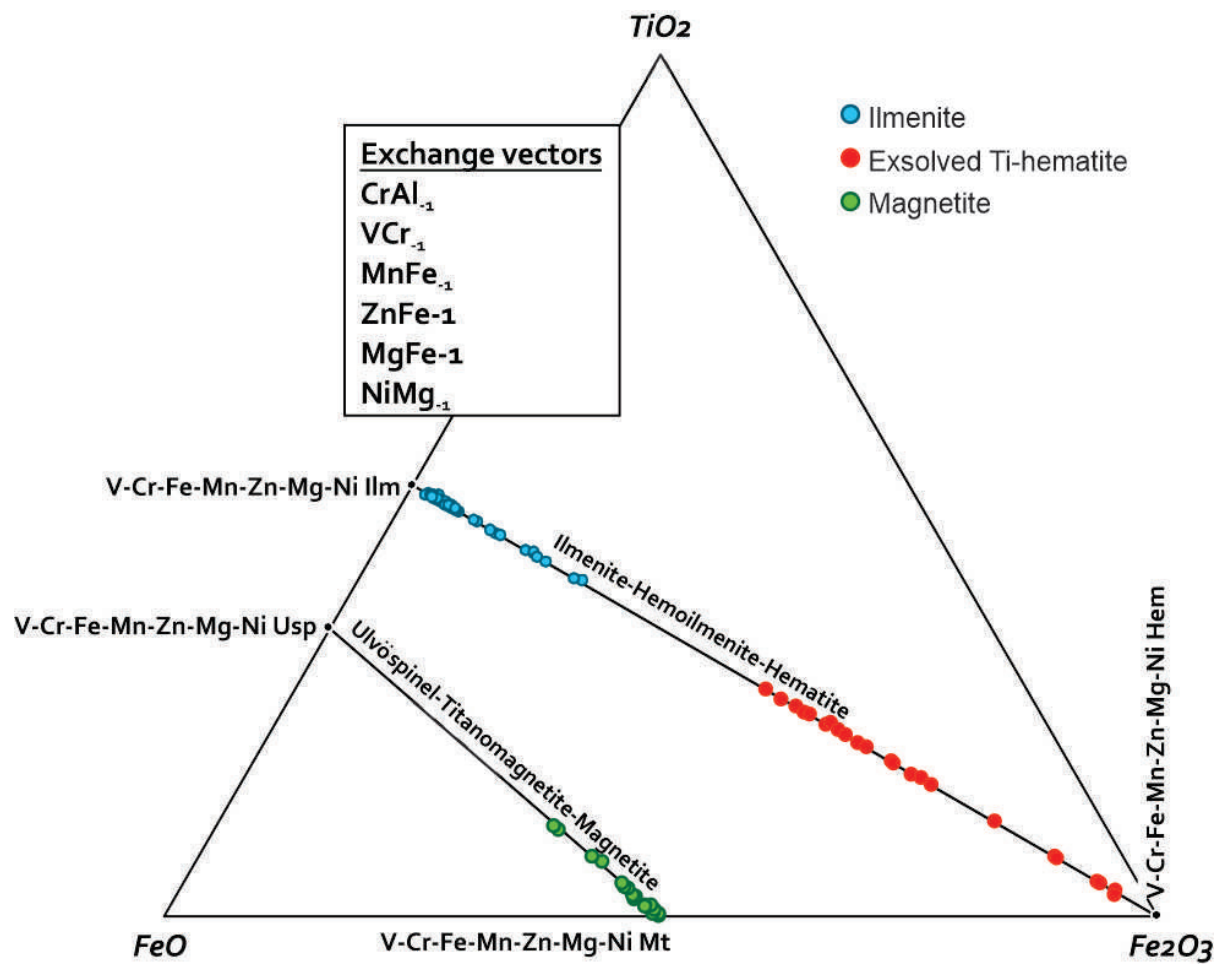

Figure 7 Ternary plot representing the composition of ilmenite, magnetite and hematite within the ilmenite-hematite and ulvöspinelmagnetite solid solutions in the SNSM. IIm = ilmenite $\left(\mathrm{Fe}^{2}+\mathrm{TiO}_{3}\right)$, Hem = hematite $\left(\mathrm{Fe}^{3+}{ }_{2} \mathrm{O}_{3}\right)$, Usp $=$ ulvöspinel $\left(\mathrm{Fe}^{2+}{ }_{2} \mathrm{TiO}_{4}\right)$, Mt $=$ magnetite $\left(\mathrm{Fe}^{2+} \mathrm{Fe}^{3+}{ }_{2} \mathrm{O}_{4}\right), \mathrm{Rt}=$ rutile $\left(\mathrm{TiO}_{2}\right)$. Diagram build using CSpace software from Torres-Roldán et al. (2000).

3.8 wt $\% \mathrm{TiO}_{2}$. Also in the banded nelsonite, the amount of $\mathrm{Cr}$ is relatively high with an average of 0.25 and a maximum of 3.4 wt $\% \mathrm{Cr}_{2} \mathrm{O}_{3}$, while $\mathrm{V}$ content is $0.4 \mathrm{wt} \%$ on average, but reaching 0.78 wt $\% \mathrm{~V}_{2} \mathrm{O}_{3}$. Magnetite in the oxide-apatite norite mineralization contains 0.02 wt $\% \mathrm{Cr}_{2} \mathrm{O}_{3}$ and $0.5 \mathrm{wt} \% \mathrm{~V}_{2} \mathrm{O}_{3}$ on average. The presence of magnetite is outlined by the Fe predominance in the qualitative element maps in Figure 8b and 8c.

\section{Discussion}

The mineralogy and textures observed in the Fe-Ti(-V) oxides record the magmatic evolution, the cooling history and later modifications (e.g., metamorphism) of the ores. Textures observed in both ilmenite and magnetite are the response of changes in the physical conditions and chemical composition during and after crystallization from a melt (Craig, 2001).
Firstly, according to Alfonso et al. (1990) and Tschanz et al. (1969), the mineralization in SNSM is associated with magmatic segregation processes that formed both banded nelsonite and oxide-apatite norite ores with little or no continuity. Many hypotheses explain the formation of $\mathrm{Fe}-\mathrm{Ti}(-\mathrm{V})$ oxide deposits. One hypothesis involves fractional crystallization. Anorthosite parent magmas and their residual liquids are Ti-rich, which may enable the early saturation and crystallization of ilmenite.

However, the calculated cotectic proportion of ilmenite in a ferrobasaltic liquid is not enough to produce an ore deposit, so ilmenite enrichment processes are required (Charlier et al., 2015; and references therein). Another hypothesis is magma immiscibility, which leads to the formation of cumulates, by segregation from a Fe-rich immiscible melt. Ilmenite and apatite could form before ferromagnesian silicates, while plagioclase, with lower density, could be separated by flotation. However, this hypothesis cannot be applied to 
Table 1. Whole-rock chemical data for the Fe-Ti ore deposits in the SNSM.

\begin{tabular}{|c|c|c|}
\hline Locality & \multicolumn{2}{|c|}{ Quebrada El Hierro } \\
\hline Type & Banded nelsor & e-apatite norite \\
\hline Coord. N & \multicolumn{2}{|c|}{$\begin{array}{c}\text { Banded nelsonite } \\
11^{\circ} 10^{\prime} 23.47^{\prime \prime}\end{array}$} \\
\hline Coord. W & \multicolumn{2}{|c|}{$73^{\circ} 39^{\prime} 57.51^{\prime \prime}$} \\
\hline Sample & NEL002I & NEL002J \\
\hline $\mathrm{SiO}_{2}$ (wt. \%) & 0.6 & 27.95 \\
\hline $\mathrm{TiO}_{2}$ & 30.27 & 11.04 \\
\hline $\mathrm{Al}_{2} \mathrm{O}_{3}$ & 0.92 & 2.8 \\
\hline $\mathrm{Fe}_{2} \mathrm{O}_{3}$ & 51.87 & 32.63 \\
\hline $\mathrm{MgO}$ & 1.71 & 6.68 \\
\hline $\mathrm{MnO}$ & 0.165 & 0.401 \\
\hline $\mathrm{CaO}$ & 8.72 & 11.6 \\
\hline $\mathrm{Na}_{2} \mathrm{O}$ & 0.01 & 0.22 \\
\hline $\mathrm{K}_{2} \mathrm{O}$ & 0.01 & 0.07 \\
\hline $\mathrm{P}_{2} \mathrm{O}_{5}$ & 6.76 & 6.25 \\
\hline LOI & -2.17 & 0.69 \\
\hline Sum & 98.865 & 100.331 \\
\hline Sc $(p p m)$ & 42 & 44 \\
\hline $\mathrm{Be}$ & $<1$ & $<1$ \\
\hline $\mathrm{V}$ & 1857 & 569 \\
\hline $\mathrm{Cr}$ & 280 & $<20$ \\
\hline Co & 60 & 71 \\
\hline $\mathrm{Ni}$ & $<20$ & $<20$ \\
\hline $\mathrm{Cu}$ & $<10$ & 50 \\
\hline $\mathrm{Zn}$ & 100 & 250 \\
\hline $\mathrm{Ga}$ & 10 & 11 \\
\hline $\mathrm{Ge}$ & $<1$ & 1 \\
\hline As & $<5$ & $<5$ \\
\hline $\mathrm{Rb}$ & $<2$ & 2 \\
\hline $\mathrm{Sr}$ & 160 & 106 \\
\hline $\mathrm{Y}$ & 48 & 81 \\
\hline $\mathrm{Zr}$ & 79 & 257 \\
\hline $\mathrm{Nb}$ & 23 & 14 \\
\hline Mo & $<2$ & $<2$ \\
\hline $\mathrm{Ag}$ & $<0.5$ & 0.7 \\
\hline In & $<0.2$ & $<0.2$ \\
\hline $\mathrm{Sn}$ & 25 & 4 \\
\hline $\mathrm{Sb}$ & $<0.5$ & $<0.5$ \\
\hline Cs & $<0.5$ & $<0.5$ \\
\hline $\mathrm{Ba}$ & 12 & 6 \\
\hline $\mathrm{Bi}$ & $<0.4$ & $<0.4$ \\
\hline $\mathrm{La}$ & 29.8 & 40 \\
\hline $\mathrm{Ce}$ & 80 & 114 \\
\hline $\operatorname{Pr}$ & 12.6 & 18.3 \\
\hline $\mathrm{Nd}$ & 67.4 & 98.6 \\
\hline $\mathrm{Sm}$ & 16.3 & 24.1 \\
\hline $\mathrm{Eu}$ & 3.72 & 5.17 \\
\hline $\mathrm{Gd}$ & 16.3 & 24 \\
\hline $\mathrm{Tb}$ & 2.1 & 3.1 \\
\hline Dy & 10.6 & 16.6 \\
\hline Ho & 1.8 & 3 \\
\hline $\mathrm{Er}$ & 4.3 & 7.2 \\
\hline $\mathrm{Tm}$ & 0.52 & 0.88 \\
\hline $\mathrm{Yb}$ & 2.7 & 5.1 \\
\hline $\mathrm{Lu}$ & 0.35 & 0.71 \\
\hline $\mathrm{Hf}$ & 3.6 & 5.8 \\
\hline $\mathrm{Ta}$ & 1.6 & 0.8 \\
\hline $\mathrm{W}$ & 6 & 1 \\
\hline $\mathrm{Tl}$ & $<0.1$ & $<0.1$ \\
\hline $\mathrm{Pb}$ & $<5$ & $<5$ \\
\hline Th & 0.4 & 0.1 \\
\hline $\mathrm{U}$ & 0.2 & 0.1 \\
\hline
\end{tabular}

the formation of deposits with only ilmenite, and enrichment processes are also necessary. Finally, variations of $\mathrm{Cr}$ in ilmenite along the ilmenite deposit of Lac Tio (Canada) suggest the possibility of various magma pulses, and alternating fractional crystallization and magma mixing stages (Charlier et al., 2015; and references therein).

On one hand, the origin of nelsonites in the Grader layered intrusion (including nelsonites, massive oxides and oxide-apatite gabbronorites), near the Tio Mine, has been interpreted as successive liquidus phases from a continuous fractional crystallization process, with ilmenite and plagioclase followed by apatite, orthopyroxene+magnetite, and finally clinopyroxene, with possible gravitational segregation of ilmenite and apatite from plagioclase (Charlier et al., 2008). On the other hand, the oxide-apatite norite would develop dykes and sheets, formed by filter pressing of magmas successively depleted in $\mathrm{Si}, \mathrm{Al}$, alkali, and enriched in $\mathrm{Fe}, \mathrm{Ti}$ and $\mathrm{P}$. These would represent late stages of the evolution of these magmas, comagmatic with the anorthositic rocks, as suggested by McLelland et al. (1994). However, the limited availability of data regarding the spatial distribution and chemical variations in a larger scale of SNSM, and their relationships with the anorthosite host do not allow further constraining of the formation of the studied Fe-Ti(-V) oxide ores.

The liquid temperature at which the $\mathrm{Fe}-\mathrm{Ti}(-\mathrm{V})$ oxide cumulates might have formed was experimentally established between 1100 to $1200^{\circ} \mathrm{C}$ in a jotunite parental magma for the associated anorthosites in the Rogaland ilmenite deposit (Duchesne and Liégeois, 2015). Nevertheless, according to Charlier et al. (2015), the emplacement of ilmenite deposits as a melt is highly questionable due to its high melting point, at least $1365^{\circ} \mathrm{C}$, too high for a melt in the crust. Carmichael (1966) concluded that ilmenite, magnetite or both are the first minerals to crystallize. The SNSM oxide ores are characterized by dominant ilmenite coexisting with minor magnetite. According to McEnroe et al. (2004), the first oxide to crystallize from the magma is ilmenite, followed by magnetite, as a 
Table 2. Representative EMP analyses of ilmenite from the SNSM.

\begin{tabular}{|c|c|c|c|c|c|c|c|c|c|c|c|c|}
\hline Locality & \multicolumn{12}{|c|}{ Quebrada El Hierro } \\
\hline Type & \multicolumn{9}{|c|}{ Banded nelsonite } & \multicolumn{3}{|c|}{ Oxide-apatite norite } \\
\hline No. & \multicolumn{9}{|c|}{ NEL002I } & \multicolumn{3}{|c|}{ NEL002J } \\
\hline Label & $8-3$ & $8-4$ & $8-5$ & $8-6$ & $8-9$ & $10-17$ & $9-49$ & $9-50$ & $9-55$ & $5-91$ & $5-92$ & $5-93$ \\
\hline $\mathrm{SiO}_{2}(w t . \%)$ & 0.02 & 0.01 & 0.00 & 0.01 & 0.04 & 0.00 & 0.00 & 0.03 & 0.00 & 0.00 & 0.00 & 0.00 \\
\hline $\mathrm{Al}_{2} \mathrm{O}_{3}$ & 0.01 & 0.00 & 0.02 & 0.05 & 0.03 & 0.02 & 0.04 & 0.00 & 0.03 & 0.00 & 0.00 & 0.02 \\
\hline $\mathrm{Cr}_{2} \mathrm{O}_{3}$ & 0.08 & 0.00 & 0.00 & 0.05 & 0.01 & 0.06 & 0.02 & 0.07 & 0.02 & 0.00 & 0.00 & 0.02 \\
\hline$\overline{\mathrm{TiO}_{2}}$ & 47.12 & 47.03 & 42.10 & 41.56 & 48.26 & 47.87 & 48.21 & 48.10 & 47.38 & 49.24 & 50.14 & 49.62 \\
\hline $\mathrm{MgO}$ & 1.83 & 1.83 & 1.56 & 1.72 & 1.80 & 1.86 & 1.80 & 1.82 & 1.86 & 0.02 & 0.09 & 0.04 \\
\hline $\mathrm{Na} 2 \mathrm{O}$ & 0.00 & 0.00 & 0.00 & 0.00 & 0.00 & 0.00 & 0.00 & 0.00 & 0.03 & 0.02 & 0.00 & 0.00 \\
\hline $\mathrm{F}$ & 0.08 & 0.00 & 0.02 & 0.24 & 0.00 & 0.00 & 0.08 & 0.00 & 0.00 & 0.14 & 0.14 & 0.04 \\
\hline $\mathrm{V}_{2} \mathrm{O}_{3}$ & 0.48 & 0.46 & 0.49 & 0.49 & 0.47 & 0.53 & 0.46 & 0.41 & 0.47 & 0.39 & 0.44 & 0.40 \\
\hline $\mathrm{MnO}$ & 0.27 & 0.25 & 0.22 & 0.23 & 0.25 & 0.18 & 0.25 & 0.25 & 0.25 & 1.44 & 1.49 & 1.55 \\
\hline $\mathrm{FeO} *$ & 38.86 & 38.72 & 34.80 & 34.06 & 39.94 & 39.50 & 39.86 & 39.72 & 38.82 & 42.63 & 43.40 & 42.89 \\
\hline $\mathrm{Fe}_{2} \mathrm{O}_{3} *$ & 11.82 & 12.24 & 21.34 & 22.42 & 9.49 & 10.65 & 10.18 & 10.13 & 11.81 & 6.76 & 6.29 & 6.10 \\
\hline $\mathrm{NiO}$ & 0.00 & 0.02 & 0.01 & 0.02 & 0.00 & 0.04 & 0.02 & 0.02 & 0.00 & 0.00 & 0.00 & 0.00 \\
\hline $\mathrm{ZnO}$ & 0.00 & 0.03 & 0.02 & 0.01 & 0.04 & 0.01 & 0.02 & 0.05 & 0.04 & 0.07 & 0.00 & 0.07 \\
\hline $\mathrm{CaO}$ & 0.00 & 0.00 & 0.00 & 0.00 & 0.00 & 0.00 & 0.00 & 0.00 & 0.01 & 0.00 & 0.02 & 0.00 \\
\hline$\overline{\mathrm{K}_{2} \mathrm{O}}$ & 0.00 & 0.00 & 0.01 & 0.00 & 0.00 & 0.00 & 0.00 & 0.00 & 0.01 & 0.00 & 0.00 & 0.01 \\
\hline $\mathrm{Cl}$ & 0.00 & 0.00 & 0.01 & 0.00 & 0.00 & 0.01 & 0.00 & 0.01 & 0.00 & 0.01 & 0.00 & 0.00 \\
\hline Sum & 00.57 & 100.61 & 100.59 & 100.87 & 100.33 & 100.73 & 100.94 & 100.61 & 100.74 & 100.71 & 102.01 & 100.76 \\
\hline Si (a.p & 0.00 & 0.00 & 0.00 & 0.00 & 0.00 & 0.00 & 0.00 & 0.00 & 0.00 & 0.00 & 0.00 & 0.00 \\
\hline $\mathrm{Al}$ & 0.00 & 0.00 & 0.00 & 0.00 & 0.00 & 0.00 & 0.00 & 0.00 & 0.00 & 0.00 & 0.00 & 0.00 \\
\hline$\overline{\mathrm{Cr}}$ & .00 & 0.00 & 0.00 & 0.00 & 0.00 & 0.00 & 0.00 & 0.00 & 0.00 & 0.00 & 0.00 & 0.00 \\
\hline$\overline{\mathrm{Ti}}$ & 0.88 & 0.88 & 0.79 & 0.78 & 0.90 & 0.89 & 0.90 & 0.90 & 0.89 & 0.93 & 0.94 & 0.94 \\
\hline $\mathrm{Mg}$ & 0.07 & 0.07 & 0.06 & 0.06 & 0.07 & 0.07 & 0.07 & 0.07 & 0.07 & 0.00 & 0.00 & 0.00 \\
\hline $\mathrm{Na}$ & 0.00 & 0.00 & 0.00 & 0.00 & 0.00 & 0.00 & 0.00 & 0.00 & 0.00 & 0.00 & 0.00 & 0.00 \\
\hline $\mathrm{V}$ & 0.01 & 0.01 & 0.01 & 0.01 & 0.01 & 0.01 & 0.01 & 0.01 & 0.01 & 0.01 & 0.01 & 0.01 \\
\hline $\mathrm{Mn}$ & 0.01 & 0.01 & 0.00 & 0.00 & 0.01 & 0.00 & 0.01 & 0.01 & 0.01 & 0.03 & 0.03 & 0.03 \\
\hline $\mathrm{Ni}$ & 0.00 & 0.00 & 0.00 & 0.00 & 0.00 & 0.00 & 0.00 & 0.00 & 0.00 & 0.00 & 0.00 & 0.00 \\
\hline$\overline{\mathrm{Zn}}$ & 0.00 & 0.00 & 0.00 & 0.00 & 0.00 & 0.00 & 0.00 & 0.00 & 0.00 & 0.00 & 0.00 & 0.00 \\
\hline$\overline{\mathrm{Ca}}$ & 0.00 & 0.00 & 0.00 & 0.00 & 0.00 & 0.00 & 0.00 & 0.00 & 0.00 & 0.00 & 0.00 & 0.00 \\
\hline $\mathrm{K}$ & 0.00 & 0.00 & 0.00 & 0.00 & 0.00 & 0.00 & 0.00 & 0.00 & 0.00 & 0.00 & 0.00 & 0.00 \\
\hline $\mathrm{Fe}^{2+}$ & 0.81 & 0.81 & 0.73 & 0.71 & 0.83 & 0.82 & 0.83 & 0.83 & 0.81 & 0.90 & 0.90 & 0.90 \\
\hline $\mathrm{Fe}^{3+}$ & 0.222 & 0.229 & 0.402 & 0.422 & 0.178 & 0.199 & 0.190 & 0.190 & 0.221 & 0.128 & 0.118 & 0.115 \\
\hline $\mathrm{Ilm}^{* *}$ & 81.4 & 81.1 & 73.4 & 71.8 & 83.8 & 82.7 & 83.2 & 83.1 & 81.4 & 90.4 & 90.6 & 90.7 \\
\hline $\operatorname{Hem}^{* *}$ & 11.1 & 11.5 & 20.2 & 21.3 & 9.0 & 10.0 & 9.6 & 9.5 & 11.1 & 6.4 & 5.9 & 5.8 \\
\hline $\mathrm{Gk}^{* *}$ & 6.8 & 6.8 & 5.9 & 6.5 & 6.7 & 6.9 & 6.7 & 6.8 & 7.0 & 0.1 & 0.3 & 0.2 \\
\hline $\mathrm{Pph}^{* *}$ & 0.6 & 0.5 & 0.5 & 0.5 & 0.5 & 0.4 & 0.5 & 0.5 & 0.5 & 3.1 & 3.2 & 3.3 \\
\hline
\end{tabular}

result of a later reduction of the magma. However, this can also be explained by the observation that the presence of magnetite is controlled by $f \mathrm{O}_{2}$, whereas the saturation of ilmenite is determined by $\mathrm{TiO}_{2}$ (Toplis and Carroll, 1995). Hence, a melt in oxidizing conditions but a high $\mathrm{TiO}_{2}$ can reach ilmenite saturation before magnetite (Charlier et al., 2015; and references therein). Secondly, both ilmenite and magnetite in SNSM display subsolvus 

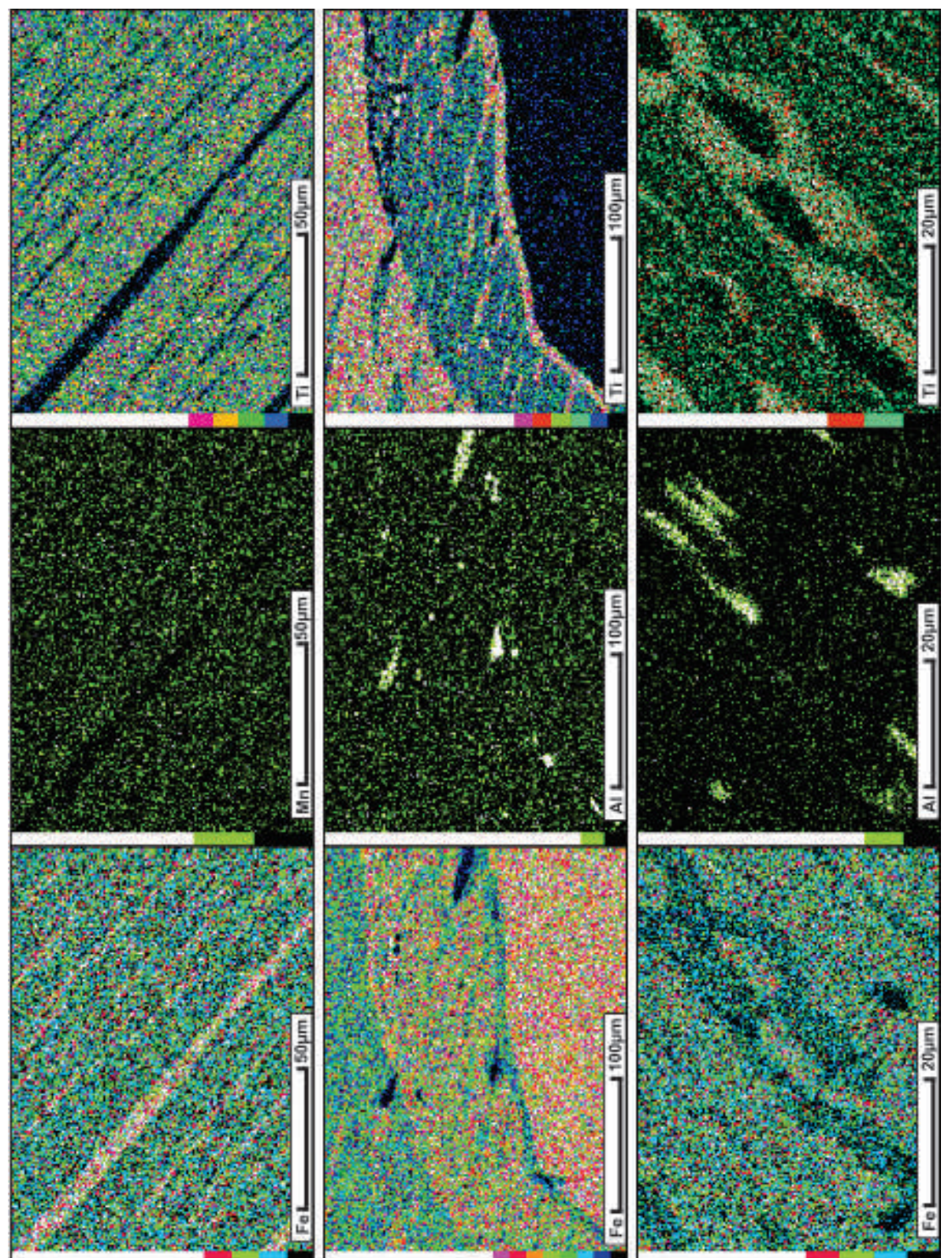

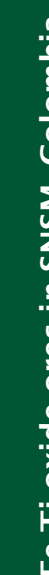
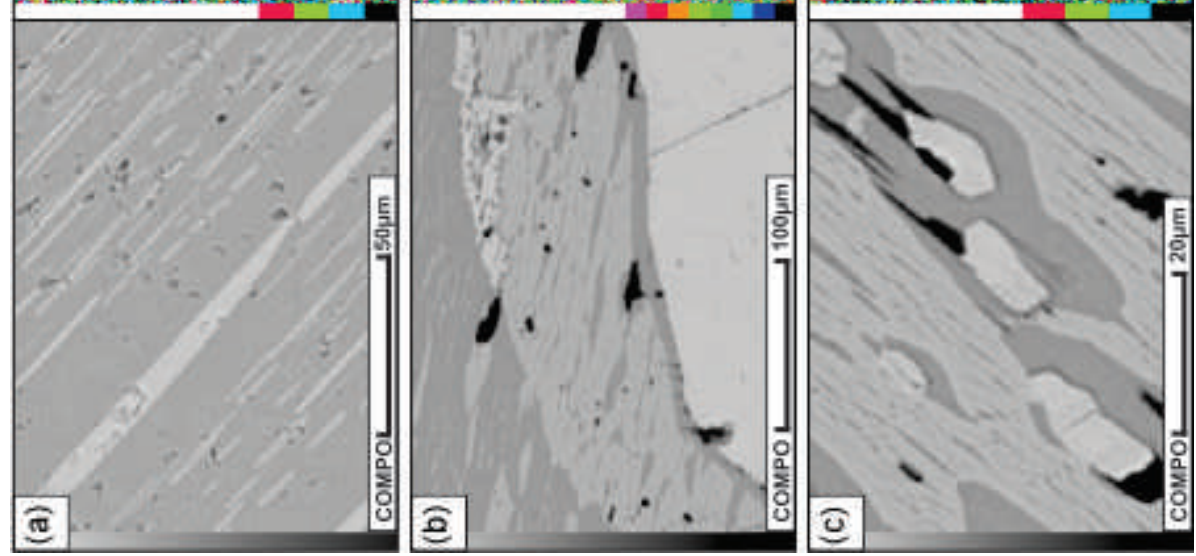

Figure 8 BSE images (left) and Fe, Al, Ti and Mn X-ray maps displaying hematite exsolutions in ilmenite, and magnetite in the banded nelsonite. (a) ilmenite with hematite lamellae; (b) halo of inverse exsolution around a magnetite grain (light gray) where titaniferous hematite contains ilmenite lamellae. Note the intermediate colors in the Fe and Ti maps for the titaniferous hematite exsolved area around magnetite. (c) Micrometer sized, rounded magnetite grains (light gray) within ilmenite-hematite, exsolutions. 


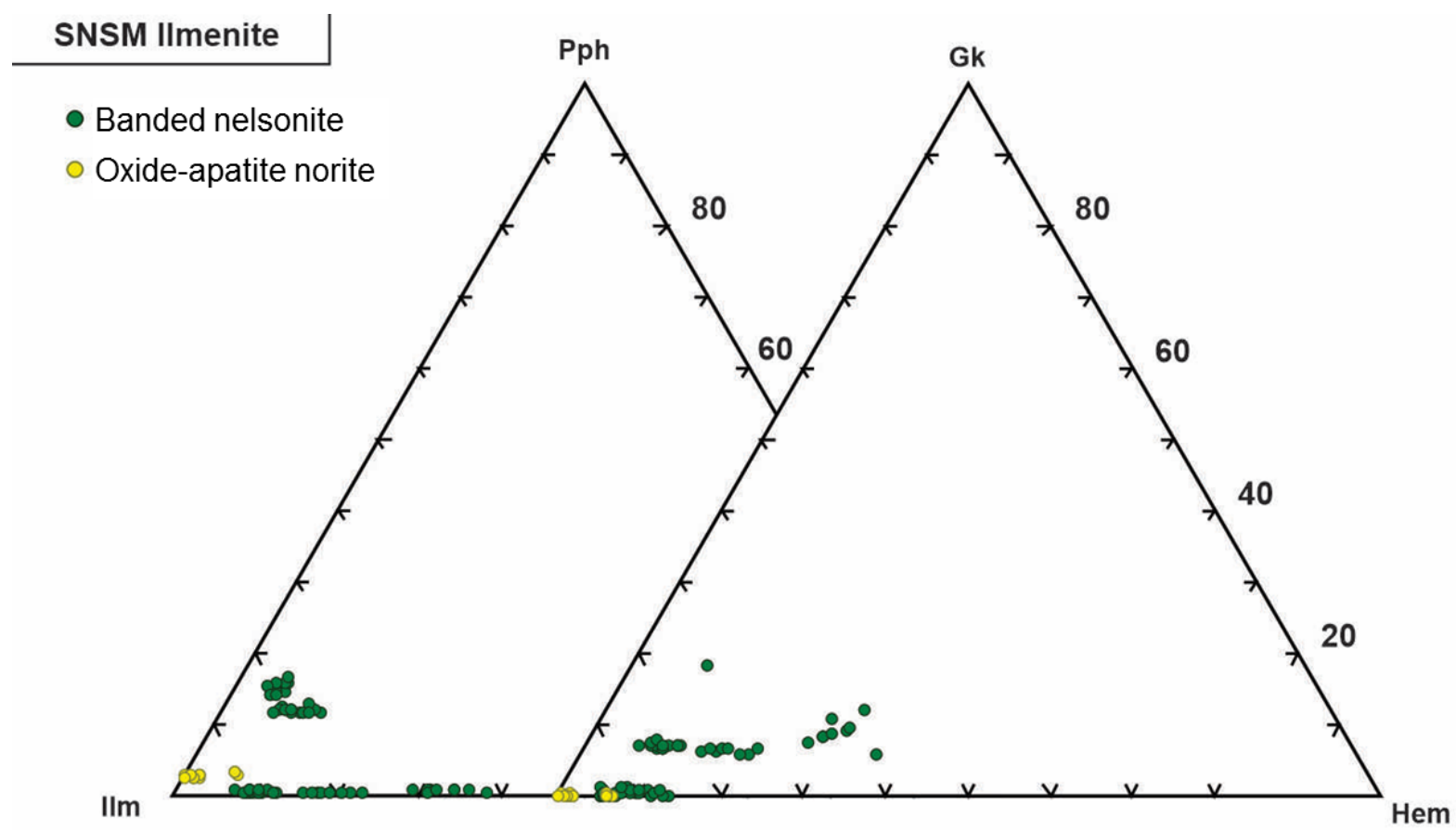

Figure 9 Triangular plots showing the ilmenite (IIm)-pyrophanite (Pph)-hematite (Hem) (left) and ilmenite (IIm)-geikielite (Gk)-hematite (Hem) (right) components of ilmenite in the SNSM.

isochemical (Arguin et al., 2018; and references therein). McEnroe et al. (2002) pointed out that the equilibrium recrystallization occurred prior to the low temperature exsolution process, since every ilmenite grain has its own set of $\{0001\}$ planes in different directions, and is interrupted by grain boundaries, as the textures observed in the SNSM banded nelsonite (Figures 5a and 5b). Carmichael (1961) established that the temperature of the hemo-ilmenite Precambrian deposits of Allard Lake (Québec) was between $575-600^{\circ} \mathrm{C}$ when the hematite lamellae exsolved, and that these conditions were maintained during a long period of time. Alternatively, in studies combining mineral chemistry and magnetism, thermodynamic models indicate that there is a miscibility gap below $700-800^{\circ} \mathrm{C}$ between a paramagnetic hematite-rich phase and a paramagnetic ilmenite-rich phase (McEnroe et al., 2007). As temperature decreases, canted ferromagnetism in hematite appears at lower temperatures (McEnroe et al., 2007).

Balsley and Buddington (1958) already stated that the number and size of hematite lamellae are related to the hematite component in ilmenite: exsolutions are not visible for Hem below $7 \mathrm{~mol} \%$; exsolutions appear when Hem exceeds 7-9 mol \%; and when Hem is above $18 \mathrm{~mol}^{\%}$, two generations may appear. This is coherent with the textures and mineral chemistry obtained in the banded nelsonite of the SNSM (4.4-22.4 wt $\% \mathrm{Fe}_{2} \mathrm{O}_{3}, 4.5$ $21.3 \mathrm{~mol} \% \mathrm{Hem}$ in the banded nelsonite, with two generations of exsolutions; and 6.1-6.8 $\mathrm{wt}^{\mathrm{0}} \% \mathrm{Fe}_{2} \mathrm{O}_{3}$, 5.8-6.5 mol \% Hem in the oxide-apatite norite , with smaller and fewer exsolutions). According to $\mathrm{X}$-ray diffraction and Curie point studies in Allard Lake by Carmichael (1961), the small hematite lamellae exsolved at a lower temperature and later than the larger lamellae. In particular, Carmichael (1961) suggested that the smaller lamellae might have formed during erosion that enabled the Allard Lake deposits to outcrop. McEnroe et al. (2002) were able to analyze both sets of lamellae by EMP and transmission electron microscopy, and determined that the original ilmenite, Ti-poor (Ilm84) would exsolve at high temperature to form Ilm94 host and micrometer-sized Ilm23 lamellae. Further cooling would produce nanometer-sized Ilm15 surrounded by Ilm98 hosts. The fact that the smaller lamellae would be richer in hematite, if exsolution was so quick that the larger lamellae 
Table 3. Representative EMP analyses of Ti-hematite lamellae from the SNSM.

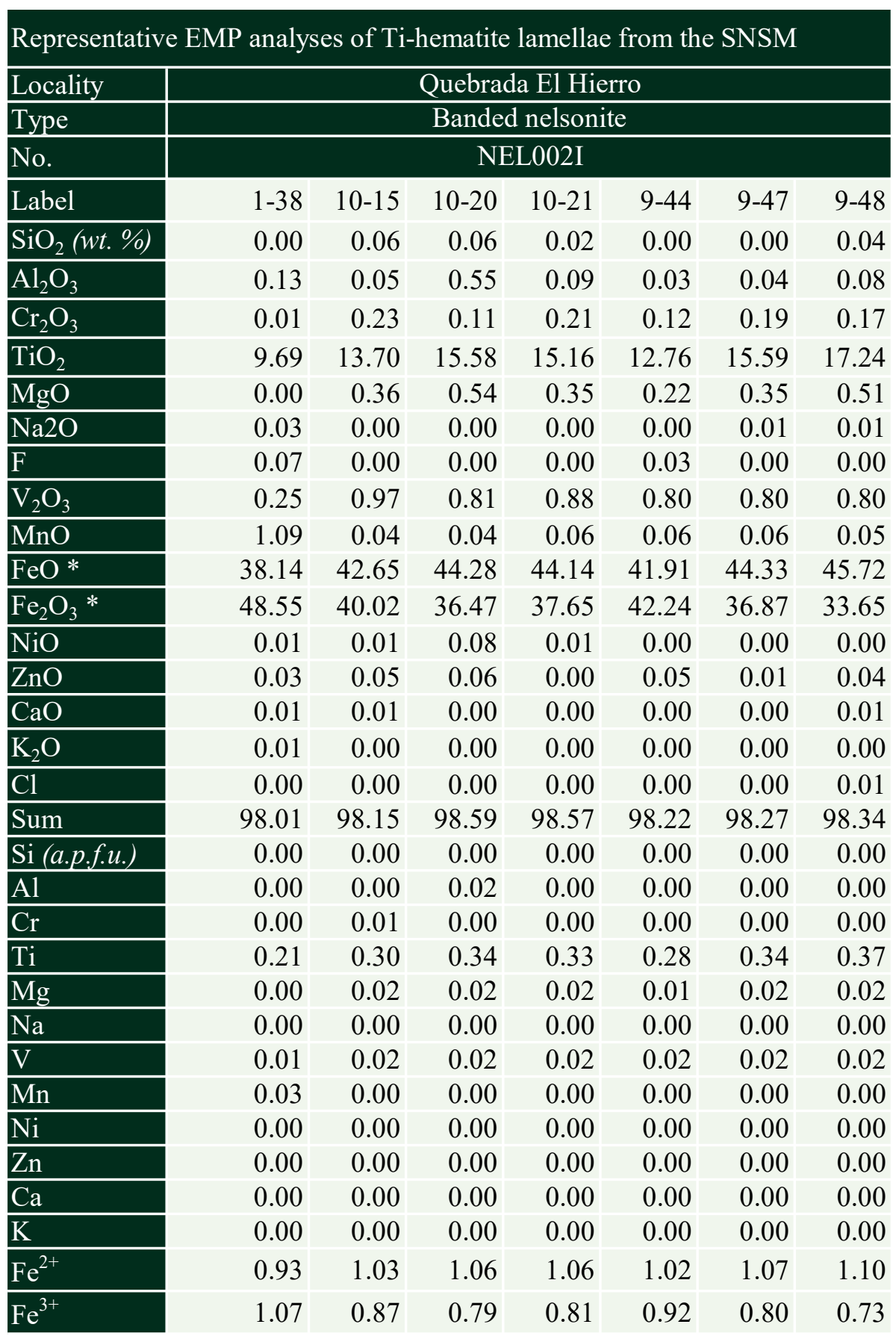

a.p.f.u. $=$ atoms per formula unit

* Calculated

would not have reached equilibrium, was also predicted by Carmichael (1961).

Extensive diffusion of $\mathrm{Fe}^{2+}, \mathrm{Fe}^{3+}$ and $\mathrm{Ti}+\mathrm{Fe}^{3+}$ from the Ilm-Hemss not only yields the formation of the exsolved lamellae but also generates relatively large areas of exsolution-free haloes (Arguin et al.,
2018), as the ones seen in Figure 5d. In any case, it should be noted that most thermodynamic and experimental approaches to the Fe-Ti oxide system do not take into account the effect of components other than $\mathrm{Ti}, \mathrm{Fe}^{2+}$ and $\mathrm{Fe}^{3+}$ (e.g., $\mathrm{Mg}$ and $\mathrm{Mn}$ ) and only apply to certain pressure ranges (Robinson $e t$ 
Table 4. Representative EMP analyses of magnetite from the SNMS.

\begin{tabular}{|c|c|c|c|c|c|c|c|c|c|c|c|}
\hline Locality & \multicolumn{11}{|c|}{ Quebrada El Hierro } \\
\hline Type & \multicolumn{8}{|c|}{ Banded nelsonite } & \multicolumn{3}{|c|}{ Oxide-apatite norite } \\
\hline Sample & \multicolumn{8}{|c|}{ NEL002I } & \multicolumn{3}{|c|}{ NEL002J } \\
\hline Label & $1-1$ & $1-5$ & $1-8$ & $1-45$ & $1-46$ & $10-38$ & $10-40$ & $9-42$ & $5-88$ & $5-89$ & $5-90$ \\
\hline $\mathrm{SiO}_{2}$ (wt. \%) & 0.03 & 0.01 & 0.05 & 0.01 & 0.04 & 0.01 & 0.03 & 0.00 & 0.03 & 0.03 & 0.00 \\
\hline $\mathrm{Al}_{2} \mathrm{O}_{3}$ & 0.26 & 0.21 & 0.19 & 0.28 & 0.33 & 0.10 & 0.95 & 0.07 & 0.45 & 0.28 & 0.18 \\
\hline $\mathrm{Cr}_{2} \mathrm{O}_{3}$ & 0.04 & 0.03 & 0.07 & 0.01 & 0.00 & 0.37 & 0.31 & 3.39 & 0.00 & 0.04 & 0.02 \\
\hline $\mathrm{TiO}_{2}$ & 0.06 & 0.06 & 0.15 & 0.13 & 0.11 & 1.58 & 3.76 & 0.09 & 0.63 & 0.14 & 0.29 \\
\hline $\mathrm{MgO}$ & 0.00 & 0.02 & 0.04 & 0.03 & 0.00 & 0.00 & 0.35 & 0.02 & 0.00 & 0.05 & 0.00 \\
\hline $\mathrm{Na}_{2} \mathrm{O}$ & 0.00 & 0.05 & 0.00 & 0.00 & 0.06 & 0.04 & 0.00 & 0.00 & 0.00 & 0.00 & 0.06 \\
\hline $\mathrm{F}$ & 0.00 & 0.00 & 0.00 & 0.00 & 0.00 & 0.00 & 0.00 & 0.00 & 0.00 & 0.00 & 0.00 \\
\hline $\mathrm{V}_{2} \mathrm{O}_{3}$ & 0.23 & 0.22 & 0.20 & 0.21 & 0.22 & 0.63 & 0.63 & 0.78 & 0.50 & 0.55 & 0.45 \\
\hline $\mathrm{MnO}$ & 0.04 & 0.09 & 0.08 & 0.06 & 0.05 & 0.00 & 0.03 & 0.01 & 0.04 & 0.00 & 0.02 \\
\hline $\mathrm{FeO} *$ & 30.80 & 30.47 & 30.75 & 31.25 & 31.08 & 32.42 & 34.17 & 31.10 & 32.04 & 31.56 & 31.52 \\
\hline $\mathrm{Fe}_{2} \mathrm{O}_{3} *$ & 67.61 & 67.89 & 67.45 & 68.79 & 68.78 & 65.40 & 60.30 & 64.59 & 67.56 & 68.86 & 69.18 \\
\hline $\mathrm{NiO}$ & 0.0341 & 0.01 & 0.00 & 0.00 & 0.04 & 0.12 & 0.12 & 0.12 & 0.03 & 0.04 & 0.01 \\
\hline $\mathrm{ZnO}$ & 0.0115 & 0.00 & 0.07 & 0.07 & 0.00 & 0.04 & 0.14 & 0.00 & 0.05 & 0.09 & 0.06 \\
\hline $\mathrm{CaO}$ & 0.0216 & 0.00 & 0.02 & 0.02 & 0.05 & 0.00 & 0.00 & 0.00 & 0.00 & 0.01 & 0.02 \\
\hline$\overline{\mathrm{K}_{2} \mathrm{O}}$ & 0.0000 & 0.00 & 0.00 & 0.01 & 0.00 & 0.00 & 0.00 & 0.00 & 0.00 & 0.00 & 0.00 \\
\hline $\mathrm{Cl}$ & 0.0000 & 0.00 & 0.01 & 0.00 & 0.01 & 0.01 & 0.00 & 0.00 & 0.00 & 0.00 & 0.01 \\
\hline Sum & 99.13 & 99.07 & 99.07 & 100.88 & 100.78 & 100.73 & 100.80 & 100.17 & 101.34 & 101.66 & 101.82 \\
\hline $\operatorname{Si}($ a.p.f.u.) & 0.00 & 0.00 & 0.00 & 0.00 & 0.00 & 0.00 & 0.00 & 0.00 & 0.00 & 0.00 & 0.00 \\
\hline $\mathrm{Al}$ & 0.01 & 0.01 & 0.01 & 0.01 & 0.01 & 0.00 & 0.04 & 0.00 & 0.02 & 0.01 & 0.01 \\
\hline $\mathrm{Cr}$ & 0.00 & 0.00 & 0.00 & 0.00 & 0.00 & 0.01 & 0.01 & 0.10 & 0.00 & 0.00 & 0.00 \\
\hline $\mathrm{Ti}$ & 0.00 & 0.00 & 0.00 & 0.00 & 0.00 & 0.05 & 0.11 & 0.00 & 0.02 & 0.00 & 0.01 \\
\hline$\overline{\mathrm{Mg}}$ & 0.00 & 0.00 & 0.00 & 0.00 & 0.00 & 0.00 & 0.02 & 0.00 & 0.00 & 0.00 & 0.00 \\
\hline $\mathrm{Na}$ & 0.00 & 0.00 & 0.00 & 0.00 & 0.00 & 0.00 & 0.00 & 0.00 & 0.00 & 0.00 & 0.00 \\
\hline $\begin{array}{l}\mathrm{V} \\
\end{array}$ & 0.01 & 0.01 & 0.01 & 0.01 & 0.01 & 0.02 & 0.02 & 0.02 & 0.02 & 0.02 & 0.01 \\
\hline$\overline{M n}$ & 0.00 & 0.00 & 0.00 & 0.00 & 0.00 & 0.00 & 0.00 & 0.00 & 0.00 & 0.00 & 0.00 \\
\hline $\mathrm{Ni}$ & 0.00 & 0.00 & 0.00 & 0.00 & 0.00 & 0.00 & 0.00 & 0.00 & 0.00 & 0.00 & 0.00 \\
\hline $\mathrm{Zn}$ & 0.00 & 0.00 & 0.00 & 0.00 & 0.00 & 0.00 & 0.00 & 0.00 & 0.00 & 0.00 & 0.00 \\
\hline$\overline{\mathrm{Ca}}$ & 0.00 & 0.00 & 0.00 & 0.00 & 0.00 & 0.00 & 0.00 & 0.00 & 0.00 & 0.00 & 0.00 \\
\hline $\mathrm{K}$ & 0.00 & 0.00 & 0.00 & 0.00 & 0.00 & 0.00 & 0.00 & 0.00 & 0.00 & 0.00 & 0.00 \\
\hline$\overline{\mathrm{Fe} 2+}$ & 1.00 & 0.99 & 1.00 & 1.00 & 0.99 & 1.03 & 1.08 & 1.00 & 1.02 & 1.00 & 1.00 \\
\hline$\overline{\mathrm{Fe} 3+}$ & 1.97 & 1.98 & 1.97 & 1.97 & 1.97 & 1.88 & 1.71 & 1.86 & 1.93 & 1.96 & 1.97 \\
\hline $\mathrm{Usp}^{* * *}$ & 0.58 & 0.52 & 1.30 & 1.14 & 1.00 & 12.94 & 27.99 & 0.95 & 5.43 & 1.19 & 2.51 \\
\hline
\end{tabular}

al., 2004). In parallel, a similar process takes place within the magnetite grains where spinel exsolves in the form of minute needles along the $\{100\}$ planes of magnetite, like the ones observed in Figure 5e. Turnock and Eugster (1962) found that the magnetite-hercynite solvus lies at $860 \pm 15^{\circ} \mathrm{C}$. In any case, there are very few aluminous spinel exsolutions (observed only in the banded nelsonite, Figure 5d), indicating that magnetite originally contained a very small amount of $\mathrm{Al}_{2} \mathrm{O}_{3}$. These aluminous spinel exsolutions may also occur in ilmenite, as seen in Figure $5 \mathrm{i}$ and in Charlier et al. (2006), but are less frequent. The fact that magnetite in the SNSM does not display ulvöspinel-magnetite exsolutions, and that it contains very low $\mathrm{Ti}$, implies that $\mathrm{Ti}$ was mostly spent on the crystallization of ilmenite.

Apart from that, symplectitic textures involving rutile and magnetite, similar to those observed in 
Figure $5 \mathrm{~h}$, were also described by Tan $e$ t al. (2015) in the Xinjie mafic-ultramafic Fe-Ti oxide deposit (China). These textures could be explained by a local low temperature alteration of hemo-ilmenite to magnetite + rutile under oxidizing conditions. The subsolidus oxidation of the original IlmHemss would lead to a more Fe-rich Ilm-Hemss, in turn producing a heterogeneous nucleation of rutile. The rutile growth would consume $\mathrm{Ti}^{4+}$, generating an excess of $\mathrm{Fe}^{2+}$ along the Ilm-Hemss boundary. This process enhances the diffusion of the $\mathrm{Fe}^{3+}$ from the Ilm-Hemss towards the boundary, and together with $\mathrm{Fe}^{2+}$, leads to the nucleation of magnetite between ilmenite and rutile. This process ends below $\sim 650^{\circ} \mathrm{C}$, and hematite exsolutions would start forming after.

Finally, there are mineralogical evidences that the oxide-apatite norite and the nelsonite underwent metamorphism to some extent, as exemplified for example, by the presence of amphibole and chlorite instead of pyroxene in the oxide-apatite norite (Figure 4d). Likewise, högbomite group minerals have been reported in high grade metamorphosed peraluminous or mafic rock, together with other $\mathrm{Al}$ (e.g., spinel) and $\mathrm{Ti}$ (e.g., ilmenite) minerals (Petersen et al., 1989). Furthermore, the assemblage of baddeleyite, zircon and srilankite $\left(\mathrm{Ti}_{2} \mathrm{ZrO}_{6}\right)$, associated whith ilmenite, has also been reported in a Proterozoic anorthosite-mangerite-charnokite-granite suite which underwent granulite facies metamorphism (Bingen et al., 2001). According to these authors, ilmenite (with tens of ppm $\mathrm{Zr}$ ) can exsolve baddeleyite during subsolidus cooling of the intrusion; and srilankite could be produced after a reaction between ilmenite and baddeleyite. Ultimately, during granulite facies metamorphism, zircon could form after the reaction of baddeleyite with silica (Bingen et al., 2001). However, in SNSM baddeleyite, with inclusions of srilankite and a spinel rim, is included in ilmenite, whereas in Bingen et al. (2001) baddeleyite and srilankite are mostly in the contacts with, and rarely included in, ilmenite (also coexisting with spinels, of gahnitic composition). Since the zircon coronas described in Bingen et al. (2001) and Charlier et al. (2015) do not have any systematic spatial relationship with hematite lamellae in ilmenite, these authors determined that $\mathrm{Zr}$ exsolution happened before hematite exsolution. In contrast, baddeleyite in SNSM seems to crosscut hematite, although more data are needed to obtain a solid conclusion.

\section{Conclusions}

The Fe-Ti(-V) oxide ores in the Proterozoic massif type anorthosite in SNSM display slightly differentiated REE patterns and negative Eu anomalies. According to the mineralogy, textures and mineral chemistry, two ore types were distinguished: i) oxide-apatite norite (fine grained ilmenite and magnetite disseminated in an assemblage of apatite, amphibole, chlorite, rutile and plagioclase); and ii) massive, banded nelsonite, with alternating layers of coarse grained ilmenite and magnetite, and apatite, with minor baddeleyite, srilankite and högbomite. In both, ilmenite displays different hematite exsolution features: needle-like in the oxide-apatite norite ore, and two generations of exsolutions in the banded ore (an earlier, coarser grained; and a later, finer grained). The composition of magnetite in terms of $\mathrm{Ti}$ and $\mathrm{V}$ is quite homogeneous in both ore types, whereas ilmenite has higher $\mathrm{Fe}^{3+}, \mathrm{Mn}$ and $\mathrm{Mg}$ contents in the banded ore.

The mineral assemblages and textures observed are similar to those of other major ilmenite deposits in the world, such as Lake Allard in Canada, and Tellnes in Norway. However, more information is needed concerning the spatial location of the different ore types in order to extend the knowledge on the formation of these ores.

\section{Acknowledgements}

This research would not have been possible without the help, guidance and experience of the MSc anthropologist Daniel Rodríguez and 
Fabián Vargas. We also express our gratitude to the Research Incentive Program of the University of Antioquia, to the extension programs of the Universidad Nacional de Colombia and the kind welcome of the University of Barcelona along the process. The authors are sincerely grateful to Prof Jean-Clair Duchesne, Dr Idael F. Blanco-Quintero and Alejandro Cisneros-de León, for their generous and constructive comments, which thoroughly improved the quality and accuracy of the manuscript.

\section{References}

Alfonso, R. A., González, L., Bermúdez, A., 1990, Geología y evaluación económica de los prospectos de ilmenita-magnetita del área de Don Diego. Departamento del Magdalena. Sierra Nevada de Santa Marta, Cartagena, Colombia: Instituto Nacional de Investigaciones Geológico-Mineras Ingeominas, $274 \mathrm{pp}$.

Arguin, J.-P., Pagé, P., Barnes, S.-J., Girard, R., Duran, C., 2018, An Integrated Model for Ilmenite, Al-Spinel, and Corundum Exsolutions in Titanomagnetite from OxideRich Layers of the Lac Doré Complex (Québec, Canada): Minerals, 8(11), 476. https://doi.org/10.3390/min8110476

Balsley, J. R., and Buddington, A. F.,1958,IronTitanium Oxide Minerals, Rocks and Aeromagnetic Anomalies of the Adirondack Area, New York: Economic Geology, 53(7),777-805. https://doi.org/10.2113/ gsecongeo.53.7.777

Bayona, G., Jiménez, G., Silva, C., Cardona, A., Montes, C., Roncancio, J., Cordani, U., 2010, Paleomagnetic data and $\mathrm{K}-\mathrm{Ar}$ ages from Mesozoic units of the Santa Marta massif: A preliminary interpretation for block rotation and translations: Journal of South American Earth Sciences, 29, 817-831. https://doi. org/10.1016/j.jsames.2009.10.005

Bingen, B., Austrheim, H.,Whitehouse, M., 2001, Ilmenite as a source for zirconium during high-grade metamorphism?

Textural evidence from the Caledonides of Western Norway and implications for zircon geochronology: Journal of Petrology, 42(2), 355-375. https://doi.org/10.1093/ petrology/42.2.355

Bustamante, C., Cardona, A., Saldarriaga, M., Casco, A., Valencia, V., Weber, M., 2009, Metamorfismo de los esquistos verdes y anfibolitas pertenecientes a los Esquistos de Santa Marta, Sierra Nevada de Santa Marta (Colombia): ¿registro de la colisión entre el arco Caribe y la margen suramericana?: Boletín de Ciencias de La Tierra, (25), 07-26.

Cardona, A., Valencia, V., Bustamante, C., GarcíaCasco, A., Ojeda, G., Ruiz, J., Saldarriaga, M., Weber, M., 2010a, Tectonomagmatic setting and provenance of the Santa Marta Schists, northern Colombia: Insights on the growth and approach of Cretaceous Caribbean oceanic terranes to the South American continent: Journal of South American Earth Sciences, 29(4), 784-804. https://doi. org/10.1016/j.jsames.2009.08.012

Cardona, A., Valencia, V., Garzón, A., Montes, C., Ojeda, G., Ruiz, J., Weber, M., 2010b, Permian to Triassic I to S-type magmatic switch in the northeast Sierra Nevada de Santa Marta and adjacent regions, Colombian Caribbean: Tectonic setting and implications within Pangea paleogeography: Journal of South American Earth Sciences, 29(4), 772-783.https://doi.org/10.1016/j. jsames.2009.12.005

Carmichael, C.M., 1961, The magnetic properties of ilmenite-hematite crystals: Proceedings of the Royal Society of London, Series A 243, 508-530.

Carmichael, I.S.E., 1966, The iron-titanium oxides of salic volcanic rocks and their associated ferromagnesian silicates: Contributions to Mineralogy and Petrology, 14(1), 36-64. https://doi.org/10.1007/bf00370985

Casas García, R., 2014, Caracterización petrológica de las nelsonitas precámbricas del complejo gneis Novillo, NE de México, 
Master thesis, Universidad Autónoma de Nuevo León, 206 pp.

Casquet, C., Pankhurst, R. J., Rapela, C. W., Galindo, C., Dahlquist, J., Baldo, E., Saavedra, J., Casado, J. G., and Fanning, C., 2005, Grenvillian massif-type anorthosites in the Sierras Pampeanas: Journal of the Geological Society, 162 (1), 9-12. https:// doi.org/10.1144/0016-764904-100

Charlier, B., Namur, O., Bolle, O., Latypov, R., Duchesne, J.G., 2015, Fe-Ti-V-P ore deposits associated with Proterozoic massiftype anorthosites and related rocks: EarthScience Reviews, 141, 56-81. https://doi. org/10.1016/j.earscirev.2014.11.005

Charlier, B., Namur, O., Malpas, S., de Marneffe, C., Duchesne, J.C., Vander Auwera, J., Bolle, O., 2010, Origin of the giant Allard Lake ilmenite ore deposit (Canada) by fractional crystallization, multiple magma pulses and mixing: Lithos, 117, 119-134. https://doi. org/10.1016/j.lithos.2010.02.009

Charlier, B., Sakoma, E., Sauvé, M., Stanaway, K., Vander Auwera, J., Duchesne, J.-C., 2008, The Grader layered intrusion (Havre-SaintPierre Anorthosite, Québec) and genesis of nelsonite and other Fe-Ti-P ores: Lithos, 101, 359-378. https://doi.org/10.1016/j. lithos.2007.08.004

Chen, W. T., Zhou, M. F., Zhao, T. P., 2013, Differentiation of nelsonitic magmas in the formation of the $\sim 1.74 \mathrm{Ga}$ Damiao Fe-Ti-P ore deposit, North China: Contributions to Mineralogy and Petrology, 165(6), 1341-1362. https://doi.org/10.1007/ s00410-013-0861-x

Chemale, F., Philipp, R. P., Dussin, I. A., Formoso, M. L. L., Kawashita, K., Berttotti, A. L., 2011, Lu-Hf and U-Pb Age Determination of Capivarita Anorthosite in the Dom Feliciano Belt, Brazil: Precambrian Research, 186, 117-126. https://doi.org/10.1016/j. precamres.2011.01.005

Cisneros de León, A., Weber, B., Ortega-Gutiérrez, F., González-Guzmán, R., Maldonado, R., Solari, L., Schaaf, P., Manjarrez-Juárez, R.,
2017, Grenvillian massif-type anorthosite suite in Chiapas, Mexico: Magmatic to polymetamorphic evolution of anorthosites and their Ti-Fe ores: Precambrian Research, 295, 203-226. https://doi.org/10.1016/j. precamres.2017.04.028

Colmenares F.H., Mesa A.M., Roncancio J.H., Arciniegas E.G., Pedraza P.E., Cardona A., Romero A.J., Silva C.A., Alvarado S.I., Romero O.A., Vargas A.F., 2007, Geología de la planchas 11, 12, 13, 14, 18, 19, 20, 21, 25, 26, 27, 33 у 34. Proyecto: "Evolución geohistórica de la Sierra Nevada de Santa Marta", 401 pp.

Cortes Castillo, E., 2013, Análisis Petrogenético de las Denominadas "Anortositas" Aflorantes en la Vertiente Occidental de La Sierra Nevada de Santa Marta - Sector Río Sevilla - El Palmor (Colombia), Master thesis, Universidad Nacional de Colombia, 189 pp.

Craig, J. R., 2001, Ore-mineral textures and the tales they tell: Canadian Mineralogist, 39(4), 937-956. https://doi.org/10.2113/ gscanmin.39.4.937

Devaraju, T., Uttangi, V., and Coolen, J., 1981, Högbomite from Fe-Ti deposits of Madangere, Ankola Taluk, Karnataka: Geological Society of India, 22(9), 439-443.

Duchesne, J. C., 1970, Microtextures of Fe-Ti oxide minerals in the South-Rogaland anorthositic complex (Norway): Annales Société Géologique de Belgique, 935, 527-544.

Duchesne, J. C., 1999, Fe-Ti deposits in Rogaland anorthosites (South Norway): geochemical characteristics and problems of interpretation: Mineralium Deposita, 34, 182-198. https://doi.org/10.1007/ s001260050195

Duchesne, J. C., Liégeois, J. P., 2015, The origin of nelsonite and high-Zr ferrodiorite associated with Proterozoic anorthosite: Ore Geology Reviews, 71, 40-56. https://doi. org/10.1016/j.oregeorev.2015.05.005

Dymek, R., Owens, B., 2001, Petrogenesis of Apatite-Rich Rocks ( Nelsonites and 
Oxide-Apatite Gabbronorites) Associated with Massif Anorthosites: Economic Geology, 96(4), 797-815. https://doi.org/10.2113/ gsecongeo.96.4.797

Hargraves, R. B., 1959, Magnetic anisotropy and remanent magnetization in hemo-ilmenite from ore deposits of Allard Lake, Quebec: Journal of Geophysical Research, 64 (10), 1565-1573. https://doi.org/10.1029/ jz064i010p01565

Hébert, C., Cadieux, A.M., van Breemen, O., 2005, Temporal evolution and nature of Ti-Fe-P mineralization in the anorthosite-mangeritecharnokite-granite (AMCG) suites of the south-central Grenville Province, SaguenayLac St. Jean area, Québec, Canada: Canadian Journal of Earth Sciences, 42(10), 1865-1880. https://doi.org/10.1139/e05-050

Ibáñez-Mejía, M., Ruiz, J., Valencia, V. A., Cardona, A., Gehrels, G. E., Mora, A. R., 2011, The Putumayo Orogen of Amazonia and its implications for Rodinia reconstructions: New U-Pb geochronological insights into the Proterozoic tectonic evolution of northwestern South America: Precambrian Research, 191(1-2), 58-77. https://doi. org/10.1016/j.precamres.2011.09.005

Kroonenberg, S. B., 2018, The Proterozoic Basement of the Western Guiana Shield and the Northern Andes. In: Fabio Cediel, and Robert Peter (Ed.), Geology and Tectonics of Northwestern South America : The Pacific-Caribbean-Andean Junction, Springer. 115-192. https://doi. org/10.1007/978-3-319-76132-9_3

McEnroe, S. A., Harrison, R. J., Robinson, P., Langenhorst, F., 2002, Nanoscale haematite-ilmenite lamellae in massive ilmenite rocks: An example of "lamellar magnetism" with implications for planetary magnetic anomalies: Geophysical Journal International, 151(3), 890-912. https://doi. org/10.1046/j.1365-246x.2002.01813.x

McEnroe, S. A., Skilbrei, J. R., Robinson, P., Heidelbach, F., Langenhorst, F., and Brown,
L. L., 2004, Magnetic anomalies, layered intrusions and Mars: Geophysical Research Letters, 31(19), L19601. https://doi. org/10.1029/2004GL020640

McEnroe, S.A., Robinson, P., Langenhorst, F., Frandsen, C., Terry, M.P., Boffa Ballaran, T., 2007, Magnetization of exsolution intergrowths of hematite and ilmenite: Mineral chemistry, phase relations, and magnetic properties of hemo-ilmenite ores with micron- to nanometer-scale lamellae from Allard Lake, Québec: Journal of Geophysical Research, 112, B10103. https:// doi.org/10.1029/2007jb004973

McLelland, J., Ashwal, L., Moore, L., 1994, Composition and petrogenesis of oxide-, apatite-rich gabbronorites associated with Proterozoic anorthosite massifs: examples from the Adirondack Mountains, New York: Contributions to Mineralogy and Petrology, 116 (1-2), 225-238. https://doi. org/10.1007/bf00310702

Mohanty, J. K., Khaoash, S., Paul, A. K., 2000, Hogbomite from Fe-Ti oxide deposit, Boula-Nausahi igneous complex, Keonjhar district, Orissa, India: Acta MineralogicaPetrographica, 41, 3-8.

Montes, G., Guzmán, G., Bayona, G., Cardona, A., Valencia, V., Jaramillo, C., 2010, Clockwise rotation of the Santa Marta massif and simultaneous Paleogene to Neogene deformation of the Plato-San Jorge and Cesar-Ranchería basins: Journal of South American Earth Sciences, 29(4), 832-848. https://doi.org/10.1016/j. jsames.2009.07.010

Ordóñez, O., Pimentel, M.M., de Moraes, R., 2002, Granulitas de Los Mangos, un fragmento grenvilliano en la parte oriental de la Sierra Nevada de Santa Marta: Revista de la Academia Colombiana de Ciencias Exactas, Físicas y Naturales, 26(99), 169-179.

Ortega-Gutiérrez, F., 1978, El Gneis Novillo y rocas metamórficas asociadas en los Cañones del Novillo y de la Peregrina, área de Ciudad 
Victoria, Tamaulipas: Revista Mexicana de Ciencias Geológicas, 2, 19-30.

Ortega-Gutiérrez, F., Elías-Herrera, M., MoránZenteno, D.J., Solari, L., Weber, B., LunaGonzález, L., 2018, The pre-Mesozoic metamorphic basement of Mexico, 1.5 billion years of crustal evolution: Earth Science Reviews, 138, 2-37. https://doi. org/10.1016/j.earscirev.2018.03.006

Petersen, E. U., Essene, E. J., Peacor, D. R., Marcotty, L. A., 1989, The occurrence of högbomite in high-grade metamorphic rocks: Contributions to Mineralogy and Petrology, 101, 350-360. https://doi.org/10.1007/ BF00375319

Pindell, J. L., Higgs, R., Dewey, J. F., 1998, Cenozoic palinspastic reconstruction, paleogeographic evolution and hydrocarbon setting of the northern margin of South America. Paleogeographic Evolution and Non-Glacial Eustasy, Northern South America: Society for Sedimentary Geology Special Publication, 58, 45-85. https://doi. org/10.2110/pec.98.58.0045

Piraquive, A., 2017, Structural Framework, deformation and exhumation of the Santa Marta Schists: accretion and deformational history of a Caribbean Terrane at the north of the Sierra Nevada de Santa Marta. $\mathrm{PhD}$ Thesis, Université Grenoble Alpes, Universidad Nacional de Colombia, 394 pp.

Pouchou, J.-L., Pichoir, F., 1991, Quantitative Analysis of Homogeneous or Stratified Microvolumes Applying the Model "PAP." Plenum Press: New York, USA.

Robinson, P., Harrison, R. J., McEnroe, S. A., Hargraves, R. B., 2004, Nature and origin of lamellar magnetism in the hematiteilmenite series: American Mineralogist, 89(5-6), 725-747. https://doi.org/10.2138/ am-2004-5-607

Sauerzapf, U., Lattard, D., Burchard, M., Engelmann, R., 2008, The titanomagnetiteilmenite equilibrium: New experimental data and thermo-oxybarometric application to the crystallization of basic to intermediate rocks: Journal of Petrology, 49(6), 1161-1185. https://doi.org/10.1093/petrology/egn021

Servicio Geológico Colombiano (SGC), 2019, Estado de la Cartografía Geológica. Retrieved from http://srvags.sgc.gov.co/ Flexviewer/Estado_Cartografia_Geologica/

Solari, L.A., Keppie, J.D., Ortega-Gutiérrez, F., Cameron, K.L., Lopez, R., Hames, W.E., 2003, 990 and 1100 Ma Grenvillian tectonothermal events in the northern Oaxacan Complex, southern Mexico: roots of an orogen: Tectonophysics, 365, 257-282. https://doi.org/10.1016/s0040-1951(03)00025-8

Stormer, J. C. J., 1983, The effects of recalculation on estimates of temperature and oxygen fugacity from analyses of multicomponent iron titanium oxides: American Mineralogist, 68, 586-594.

Tan, W., Wang, C. Y., He, H., Xing, C., Liang, X., Dong, H., 2015, Magnetite-rutile symplectite derived from ilmenite-hematite solid solution in the Xinjie Fe-Ti oxide-bearing, maficultramafic layered intrusion (SW China): American Mineralogist, 100(10), 2348-2351. https://doi.org/10.2138/am-2015-5435

Toplis, M.J., Carroll, M. R., 1995, An experimental study of the influence of oxygen fugacity on Fe-Ti oxide stability, phase relations, and mineral-melt equilibria in ferrobasaltic systems: Journal of Petrology, 36(5), 1137-1170. https://doi.org/10.1093/ petrology/36.5.1137

Torres-Roldán, R., Garcia-Casco, A., GarcíaSánchez, P., 2000, CSpace: An integrated workplace for the graphical and algebraic analysis of phase assemblages on 32-bit Wintel platforms: Computers \& Geosciences, 26 (7). 779-793. https://doi.org/10.1016/ s0098-3004(00)00006-6

Tschanz, C., 1970, The mineral resorces of the Sierra Nevada de Santa Marta, Colombia (Zone 1): U.S Geological Survey.

Tschanz, C., Jimeno, A., Vesga, C., 1969, Geology of the Sierra Nevada de Santa Marta Area 
(Colombia). Geology of Northern California: California Division of Mines Bulletin, 190, 107-172.

Tschanz, G. M., Marvin, R. F., Cruz B., J., Mehnert, H.H., Gebula, G. T., 1974, Geologic Evolution of the Sierra Nevada de Santa Marta, Northeastern Colombia: Geological Society of America Bulletin, 85(2), 273-284.https:// doi.org/10.1130/0016-7606(1974)85<273:GE OTSN>2.0.CO;2

Turnock, A.C., Eugster, H.P., 1962, Fe-Al oxides: Phase relationships below $1000{ }^{\circ} \mathrm{C}$ : Journal of Petrology, 3(3), 533-565. https://doi. org/10.1093/petrology/3.3.533

Villanova-de-Benavent, C., Torró, L., CastilloOliver, M., Campeny, M., Melgarejo, J. C., Llovet, X., Galí, S., Gonçalves, A. O., 2017, Fe-Ti $(-\mathrm{V})$ Oxide Deposits of the Kunene Anorthosite Complex (SW Angola): Mineralogy and Thermo-Oxybarometry: Minerals, 7(12), 246. https://doi. org $/ 10.3390 / \mathrm{min} 7120246$

Whitney, D. L., Evans, B. W., 2010, Abbreviations for names of rock-forming minerals: American Mineralogist, 95(1), 185-187. https://doi.org/10.2138/am.2010.3371 